DOI: 10.18468/rbli.2020v3n1.p27-55

\title{
Universo lexical Aparai e Wayana e seus Empréstimos Lexicais
}

\author{
Aparai and Wayana Lexical Universe and its Lexical Loans
}

\author{
Eliane Camargo \\ I'Institut Français d'Études Andines (IFEA) \\ Centre National de la Recherche Scientifique (CNRS) \\ Latsu T. Aparai
Escola Indígena (Aldeia Bona)
}

Resumo. O presente texto trata de temas linguísticos abordados durante oficinas de língua aparai e wayana, realizadas em 2015 em duas aldeias, uma de língua predominante aparai, na aldeia Apalai, outra de língua predominante wayana, na aldeia Suwi-Suwi Min. Os temas linguísticos abordados (lexical e sintático) foi solicitado pelos participantes, com exceção da lista de palavras de Swadesh, que serviu de material de base para as oficinas. O estudo lexicográfico realizado a partir de dados coletados in situ revela o quanto os falantes se dão conta da origem das palavras recentemente emprestadas; as mais antigas como alakapuha 'espingarda' já integraram o sistema lexical não deixando mais traços de sua origem espanhola na mente dos locutores aparais e wayanas. Além de fazermos um apanhado de empréstimos linguísticos e de palavras semelhantes compartilhadas pelas duas línguas caribes, o aparai e o wayana, o presente estudo apresenta a lista de cem palavras de Swadesh nessas duas línguas caribes faladas no leste do planalto das Guianas.

Palavras chaves: Línguas Indígenas; Línguas Caribes; Planalto das Guianas; Wayana; Aparai, Línguas da Amazônia.

\begin{abstract}
The present text focusses on linguistic topics dealt with during workshops, held in two indigenous villages in 2015, one regarding Apalai, predominantly spoken in the Apalai village, the other regarding Wayana, predominantly spoken in the Suwi-Suwi Min village. The topics were explicitly asked for by the participants, with the exception of the Swadesh list which served as background material for the workshops. The lexicographic study based on data collected in situ reveals that speakers are very much aware of the origin of the recently borrowed words; older ones like alakapuha "arcabuza" 'shotgun' have already been integrated in the caribbean lexical and phonological system, leaving no trace of its Spanish origin. In addition to a list of linguistic loans and similar words shared by both languages, the study presents one hundred words from the Swadesh list in these two Caribbean languages spoken in the east of the Guyanese plateau."
\end{abstract}

Keywords: Indigenous Languages; Cariban Languages, Guyanese Plateau, Wayana, Apalai, Amazonian Languages.

\section{Introdução ${ }^{1}$}

Entre junho e julho de 2015, ocorreram duas oficinas de língua uma aparai, outra wayana, nas aldeias Bona, e Suwi-Suwi Mïn respectivamente. Elas se realizaram paralelamente às oficinas de audiovisual ${ }^{2}$

1. Eliane Camargo, etnolinguista, membro associado do Instituto Francês de Estudos Andinos (IFEA/CNRS); chefe de projetos na Ipê - Associação para o Diálogo Intercultural: pesquisa e ação. Estuda o wayana e o aparai desde 1993. Latsu T. Aparai é professor bilíngue na escola da Aldeia Bona. Ele é trilingue: wayana, tirió e aparai, sendo esta última a língua que mais pratica.

2. A oficina de vídeo foi coordenada por André Lopes; a oficina de fotografia por Paula Morgado. Ambos pesquisadores são 
solicitadas pelos jovens dessas culturas, no campo de vídeo, fotografia e som. No caso específico das oficinas de línguas, tratamos de termos técnicos diversos os quais eram discutidos nas outras oficinas - tais como 'projeto', 'produção', 'cenário', 'imagem estática' (fotografia), 'imagem dinâmica' (vídeo), 'montagem' etc. Abordamos alguns termos da informática ${ }^{3}$ e da tecnologia de celular, uma vez que estavam aprendendo a filmar e editar, os participantes gostariam de ver seus vídeos em seus telefones celulares. Neste estudo, apenas uma parte do trabalho de 'metalinguística informática' será abordada, cuja apresentação e análise de muitos dos dados foram tratados em Camargo et al. (2020)4. Nas oficinas, a lexicografia comparativa tratamos de palavras comuns entre o aparai e o wayana, e entre essas línguas e outras línguas indígenas e não indígenas. A lista de cem palavras (Morris Swadesh, 1952), consideradas recorrentes nas diferentes línguas, serviu para vermos o parentesco linguístico e para uma primeira e breve discussão sobre a necessidade de rever a grafia do aparai que é fonética, escondendo muitos fenômenos interessantes como a duração vocálica, assimilação, dissimilação e lenição - todos anotados por " $h$ ".

O presente artigo propõe uma apresentação do léxico aparai e wayana, indicando palavras compartilhadas entre essas línguas ou palavras estrangeiras incorporadas no sistema lexical de cada uma delas. Os dados lexicográficos dessas duas línguas caribes foram coletados de primeira mão, in situ, no âmbito de um projeto etnográfico durante o qual realizamos «oficinas de língua». Antes de abodar essas questões, contextualizamos sociolinguisticamente e geograficamente os aparais e os wayanas.

\section{Primeiras informações}

As línguas aparai e wayana pertencem à família linguística caribe. Ambas são faladas por grupos do mesmo nome que vivem no Suriname, na Guiana Francesa e no Brasil, tido como território tradicional dos antepassados. A população global soma cerca de 2200 indivíduos. No Barsil, há pessoas de outros grupos indígenas com quem coabitam por meio de intercasamentos: os tiriós 5 (família caribe), os tecos (teko conhecido antigamente por emerillon) e os wayampis (família tupi-guarani). Na Guiana Francesa, alguns são casados com alucus, povos afro-guianeses ${ }^{6}$. E nos três territórios há casamentos com ocidentais (brasileiros, franceses e holandeses). Os caribes dessa região do planalto guianês, o médio

antropólogos membros do Grupo de Antropologia Visual (GRAVI) da USP. A oficina de som foi coordenada por Guilherme Barros, músico e engenheiro de som. Essas oficinas realizadas a pedido do grupo fizeram parte do projeto de elaboração de um livro sobre os dois grupos já mencionado.

3. Entre 2014-2018, E. Camargo coordenou o projeto "Saberes Autoctones Wayana e Aparai (SAWA)", cujo um dos objetivos era montar o portal wayana-aparai watau. Disponível em https://watau.fr/s/watau-fra/page/accueil.

4. Disponível em https://journals.openedition.org/pds/5127.

5. Os nomes dos grupos e línguas indígenas citados nesse trabalho segue a grafia do português e não as regras ortográficas da ABA (1956).

6. Chamados de 'negros-marrons' não por referência à cor da pele mas devido ao termo espanhol 'cimarrón, cimarrona' que significa 'fugitivo', remetendo 'a uma pessoa domesticada que foge mato adentro'. O termo 'negro-marrom' refere-se aos assim antigos escravos que fugiram das plantações holandesas. 
e o alto rio Paru d'Este (aparais e wayanas?) e aqueles que ocupam o rio Paru d'Oeste ${ }^{8}$ (caxuianas, tiriós e txikiyanas), resultam de agrupamentos de sub-grupos étnicos ${ }^{9}$ de línguas próximas umas das outras. Com casamentos interétnicos, a identidade étnica se transmite via pela identidade linguística, determinada pela patrilinearidade ${ }^{10}$.

\section{Região multilíngue}

Nessa região multilíngue, muitos indivíduos são poliglotas por falar 3, 4, 5 línguas da mesma família ou de diferentes famílias linguísticas (caribe, tupi-guarani, português, francês, línguas crioulas dos afroguianeses ou crioulo francês). No rio Paru de Leste, muitos falam o wayana, o aparai, o tirió e o wayampi. Os mais velhos ainda entendem um tipo de sabir ${ }^{11}$, conhecido sob o nome de taki-taki (do inglês talktalk, sob uma base lexical inglesa), usado na relação comercial entre os afro-guianeses do Suriname e da Guiana Francesa, as diferentes populações indígenas e, atualmente, também os comerciantes chineses. Essa diversidade linguística é dinâmica em toda a região na Guiana Francesa (alto e médio rio Maroni) e no Brasil (Parque do Tumucumaque e Terra Indígena Paru d'Este). Segundo testemunhas orais, vigorava na região um tipo de exogamia linguística em que o homem procurava se casar com uma mulher de fala diferente da sua, fato linguístico que selava coesão social entre diferentes grupos da região; ainda hoje essa exogamia existe em menor escala, mas não parece ser mais um sistema social como pode ter sido outrora.

\section{O contato interétnico: wayana e aparai e o mito}

A memória dos falantes aparai aponta a região do baixo Amazonas na área dos rios Maicuru e Curuá do Norte ${ }^{12}$, afluentes do rio Amazonas, no Estado do Pará. A dos falantes wayana corresponde à região do médio e alto rio Paru e rio Jari, ambos também afluente do rio Amazonas. Os dois povos lembram que no rio Ipitinga, afluente do médio Jari, no Estado do Amapá, no passado existiam aldeias aparais. Velhos aparais testemunham que outrora, quando viviam no baixo Amazonas, faziam incursões até o rio Trombetas em busca de caça, de fibras para confeccionar seus utensílios e tabocas de boa qualidade para suas flechas. Nesse trajeto, territorialmente imenso, entravam em contato com outros grupos, fosse para trocas de objetos, fosse para contrair alianças.

7. Parte das aldeias dos aparais e os wayanas encontra-se no Parque Indígena do Tumucumaque (situado na área de preservação criada em 2002: Parque Nacional da Serra do Tumucumaque), a outra parte na Terra Indígena Rio Paru d'Este. Na primeira área, também temos povos isolados, chamados no lado brasileiro, de akurio. Alguns deles foram contactados em 1968 no Suriname e passaram a viver entre tiriós e wayana no Suriname e entre wayana na Guiana Francesa, na aldeia Elahe. Para maiores informações em Vanessa Grotti \& Marc Brightman (2016).

8. Esses dois rios encontram-se no extremo norte do Estado do Pará, embora os grupos indígenas dessa região estejam submetidos à Coordenação Regional de Amapá e Norte do Pará da FUNAI.

9. Por exemplo, o nome wayana cobre os povos upului, kukui 'vagalume' (ou kukui yana), okomo 'vespa' (ou okomo yana), opak 'rã opak' (ou opak yana). Cf. Grenand \& Grenand (1985), Gallois (1986) e Morgado (1994).

10. Camargo (1997).

11. Língua híbrida constituída de lexemas de línguas diversas usada como meio de comunicação essencialmente comercial. Refere-se a um 'falar comercial veiculado no Mediterrânceo, composto de palavras do árabe, do francês, do italiano e do espanhol'.

12. O rio Maicuru situa-se no Município de Monte Alegre e o rio Curuá no Município de Alenquer. 
Desde os anos $1960^{13}$, os povos aparai e wayana coabitam um mesmo território e formam uma sociedade por meio de intercasamentos ${ }^{14}$. A filiação étnica é dada pelo pai. Assim, a identidade étnica de um pai wayana é transmitida a seus filhos, assim como a sua filiação linguística, e vice-versa se o pai for aparai. Até meados dos anos 1990 essa regra de filiação étnica e linguística patrilinear era aplicada no rio Paru d'Este ${ }^{15}$.

Documentos históricos (HURAULT, 1968; GALLOIS, 1986; GRENAND; GRENAND, 1985) apontam para uma coabitação de mais de duzentos anos entre esses dois grupos, cada qual, por sua por sua vez, constituído de sub-grupos, frutos de coalizão de pós-guerra, de pós-epidemias ${ }^{16}$. Esta união é explicada na narrativa mítica conhecida sob o nome de Tulupele (wayana) ou Turupere (aparai) ${ }^{17}$, 'o mito da cobra grande'. A narrativa conta que no topo de uma montanha vivia um animal fabuloso (larva, jacuraru, sucuriju) muito grande, cuja existência era avisada por uma arara azul ao se aproximarem as canoas próximas da embocadura do rio Asiki no médio rio Paru d'Este. As canoas que subiam (os aparais) ou desciam (os wayanas) o rio, eram avisadas pela arara que gritava kalalam-kalalam avisando o «animaldevorador» que descia da montanha onde vivia e atacava quem passasse de canoa, matando seus ocupantes. Os familiares aparai daqueles que transitavam pelo rio Paru e não retornavam às suas aldeias pensavam que "seus parentes haviam sido atacados pelos wayanas» ou familiares wayanas «acreditavam ser os aparais que atacavam membros de sua família» (que descia o rio). Até que um dia, pajés de ambos grupos resolveram ver juntos o que ocorria; seguiram pela mata, ao longo do rio, uma canoa que navegava a fim de ver o que ocorria no local do acidente. Ao se aproximar da embocadura do rio Asiki, notaram que uma arara azul cantava ao ver uma canoa se aproximar e o Tulupele descia a montanha e atacava a canoa. Wayanas e aparais puderam ver que eles não se matavam, entre si e assim decidiram matar juntos o grande bicho e, desde então, passaram a coabitar ${ }^{18}$.

\subsection{A coabitação linguística}

A coabitação linguística contribuiu para um tipo de hibridismo de muitos conceitos e práticas socioculturais dos aparais e wayanas. Quando filho de pais de duas etnias, ele aprende as duas línguas: a da mãe e a do pai. Porém é a língua do pai representa a identidade étnica do filho (homem e mulher). Conforme a aldeia, ele aprende outras línguas como o tirió (caribes) ou o wayampi (tupi-guarani) ${ }^{19}$. A identidade linguística é transmitida por aquele que cria a pessoa, pai biológico ou pai adotivo (= padrasto), ou pela língua do pai ou padrasto da mulher que, às vezes sozinha, cria uma pessoa. Se a pessoa é criada por um homem aparai (pai biológico ou pai não biológico), o filho natural ou não

13. Morgado (1994).

14. No rio Paru, wayanas casam majoritariamente com aparais e wayampis, e aparais com wayanas e tiriós. Na Guiana Francesa, os wayanas casam-se com aparais, com wayampis, com tecos (tupi-guarani) e recentemente com kali'nas (caribe).

15. Na Guiana Francesa, no alto rio Maroni onde vivem os wayanas, essa prática sociolinguística não vigora mais, em parte devido a alfabetização ser em wayana. Todos falam o wayana mesmo o pai sendo tirió, aparai, kali'na, wayampi ou teco. Vale lembrar que nos últimos vinte anos, mulheres wayanas que se casam com tecos ou com wayampis estão morando no Leste da Guiana em território wayampi e teco.

16. Hurault (1968), Gallois (1986).

17. Camago \& Ibañez (2015, p. 82-85), Camargo \& Tapinkili (2020).

18. Van Velthem (1998).

19. Camargo (1997).

Revista Brasileira de Línguas Indígenas - RBLI

ISSN 2595-685X

https://periodicos.unifap.br/index.php/linguasindigenas

Macapá, v. 3, n. 1, p. 27-55, 2020 
será reconhecido como sendo aparai e falará aparai, e assim por diante. Essa regra de afinidade e de identidade linguística perdura ainda hoje entre esses dois grupos no rio Paru d’Este, porém a alfabetização do aparai levou muitos pais wayanas a falar o aparai para que o filho não encontrasse dificuldade de aprendizagem! Desde o início do século XXI, no rio Paru, essa situação sociolinguística levou o wayana a perder espaço e se tornar uma língua altamente vulnerável, ao passo que o aparai, apesar da reduzida população, não está ameaçado. No caso inverso, na Guiana Francesa, onde o aparai tem menos de 40 locutores, ele está bastante ameaçado de extinção.

\section{Multilinguismo}

Hoje em dia, além das línguas indígenas, as crianças aparais e wayanas falam o português no Brasil, o francês na Guiana francesa, e o sranan tongo no Suriname. Na fronteira entre o Suriname e a Guiana Francesa, elas aprendem a se comunicarem em taki-taki graças aos vendedores ambulantes (afroguianeses ou chineses) que navegam pelo rio Maroni ou ainda nos comércios rurais de Maripasula. Aos onze ou doze anos, a criança deixa a aldeia para estudar em Maripasula, onde ela aprende a falar o alucu. Depois dos quinze ou dezesseis anos, ela vai estudar nas cidades da costa atlântica onde aprendem o crioulo guianês. Desse convívio linguístico, o sistema lexical do aparai e do wayana recebeu influência lexical de diferentes línguas.

\subsection{Presença missionária e escolarização}

Nos anos 1950, Edward e Sally Koehn, missionários americanos do Summer Institute of Linguistics (SIL), começaram um trabalho de evangelização junto aos aparais na região do município de Almeirim, no Baixo Amazonas. Em parceria com a FAB, reuniram aparais e wayanas, incluindo os do Jari e Ipitinga, em uma única aldeia, nomeada Bona ${ }^{20}$, com o intuito de dar assistência médica, criar escolas e promover a conversão ao reunir a população, controlando mais facilmente os aspectos ditos «diabólicos» da cultura indígena (poligamia, tabaco, bebida fermentada, danças, xamanismo)"121.

O casal de missionários pouco sensibilizou os wayanas para o cristianismo ${ }^{22}$. Diziam aos chefes wayanas que "deveriam falar apenas aparai para escolarizar seus filhos e netos, e que dispunham da Bíblia para ler". Alguns wayanas reagiam dizendo, indignados: "Estão pedindo para eu deixar de falar a minha língua?!" (Pai de Tadeu, 1993). Porém, com a alfabetização voltada ao aparai, o casal buscou convencer o grupo, mais resistentes ao não abandono de suas práticas socioculturais. Com a alfabetização em aparai, esta língua passou a gozar de um certo prestígio linguístico e a transmissão do wayana entrou em declínio. O wayana continuou sendo falado entre os adultos (pais e avós), mas menos com as crianças. Testemunhos orais (2014-2018) contam que a transmissão voltou a decolar sem se preocuparem com a alfabetização ser em aparai ${ }^{23}$. Na Guiana francesa, todavia, deu-se o contrário. Os inter-casamentos, não apenas se davam entre wayanas e aparais, como também entre wayanas e

20. Nome dado por Manfred Rauschert que vivia na época no rio Paru d’Este, junto aos aparai.

21. Grenand \& Grenand (1985, p. 24), ACT (2007, p. 45).

22. A conversão destes foi feita no final dos anos 1990 quando pastores tiriós do Suriname chegaram no rio Paru, batizando as pessoas às vésperas do "fim do mundo".

23. Foi nesse âmbito que abecedários em wayana e em aparai foram elaborados (CAMARGO, 2015). 
wayampis e wayanas e te $\cos ^{24}$, contribuindo à caracterização de uma região multilíngue. Nessa região, o uso do wayana na alfabetização começou em $1984^{25}$ na aldeia Antecume Pata. No final dos anos 1990 a alfabetização extendeu-se nas demais escolas wayanas da área ${ }^{26}$, o que favoreceu para o prestígio da língua junto à sociedade nacional, deixando em segundo plano as demais línguas indígenas, cujo processo de transmissão diminuiu. Adultos aparais diziam que upassar a falar o wayana no cotidiano auxiliaria a criança em sua escolarização». Esta reflexão é a mesma feita por adultos wayanas no rio Paru d'Este em relação à necessidade de reforçar o uso do aparai para facilitar a alfabetização.

\subsection{Léxico aparai}

As diferentes línguas caribes faladas no extremo norte do Pará27, região onde se situa este trabalho, expressam estruturas de pensamento algumas parecidas, outras diferentes. Receberam e recebem ainda léxico de diferentes línguas presentes na região ${ }^{28}$. O léxico pode ser oriundo de uma mesma família linguística ou não, provir de grupos indígenas ou não indígenas. Tal mistura leva a um rico léxico que revela os diferentes contatos e influências linguísticas no aparai e no wayana.

Um dos primeiros autores a publicar um pequeno léxico aparai foi F. Rice (1934). Embora a obra seja interessante, notamos algumas dificuldades no sentido da tradução em inglês não corresponder ao significado na língua: por exemplo, 'man' nopo, 'woman' puete, 'wife' nopo, 'daugther' erutua ao passo que o correspondente coreto seria orutua, nohpo, pyty e enxiry, respectivamente ${ }^{29}$. Sally Koehn (1991) e Eliane Camargo (2002) elaboraram material relativo ao léxico aparai. O wayana dispõe de um dicionário analógico (CAMARGO; TAPINKILI, 2020) que indica, para muitos dos vocábulos a sua origem estrangeira. Diante da pouca produção sobre o léxico aparai e wayana, propusemos uma oficina de língua sobre "o universo lexical aparai e wayana" no âmbito de um livro em curso sobre à etnografia aparai e wayana com a participação ativa de alguns membros.

Antes de adentrar no universo lexical aparai e wayana, propomos capitular outras línguas como o português e línguas primas próximas (italiano, francês) e línguas primas não tão próximas (inglês, alemão) à partir do grego e do latim, para ilustrar que o lexico é uma parte da língua sem fronteiras. Ele viaja com os mais diferentes tipos de contatos entre línguas.

24. Na literatura, os tecos são conhecidos sob o nome de Emerillon, dito melejo em wayana.

25. Akajuli foi o primeiro monitor de língua wayana na aldeia Antecume Pata (1986-2004). Camargo \& Ibañez (2015, p. 120). 26. No final dos anos 1990, não havia alfabetização propriamente dito nas demais escolas wayana (Twenke-Taluhwen aberta em 1974, Elahe em 1985, Cayode 1991 e Pilima em 1996). No programa de "mediador bilíngue" (GOURY et al., 2002), o mediador de fala wayana e francês intervinha em classes primárias como tradutor mediando a comunicação entre o aluno e o professor francês. Desde 2010, existe nas escolas indígenas um dispositivo chamado "(aquele que) Intervém na Língua Materna" (Intervenant em Langue Maternelle). Cf. Alby \& Léglise (2017, p. 10).

27. Aparai, hixkariyana, katxuyana, tirió, txikiyana, waiwai e wayana.

28. Em Jolkesky (2016) há um vasto leque de semelhança lexical entre línguas caribes e macro-jê, entre línguas como o guató, kawapana, nambiquara, taruma, warao, arawak (ou lokono), bororo, jeoromitxi, carajá, rikbaktsa, e línguas tupi. 29. Rice coletou a sua lista lexical do aparai junto a um homem que falava pouco português. 


\section{Empréstimo linguístico}

As palavras são como elementos livres de uma língua. Elas viajam e entram em contato com outras línguas, favorecendo os empréstimos lexicais, cujo processo pode ocorrer de diferentes maneiras. Estes incorporam o sistema lexical das línguas de chegada e estas podem ou manter o sentido da língua de partida ou manter a forma da palavra e mudar de sentido.

Nas oficinas, empréstimos linguísticos onipresentes nas mais diversas línguas foram discutidos, e antes de adentrarmos nas palavras estrangeiras existentes em aparai e em wayana, apresentamos alguns termos em português ou outras línguas não indígenas vindos de outras línguas. Dentro de uma mesma família de línguas, é comum ver palavras que compartilham uma mesma raiz lexical; em alguns casos o processo derivacional é parecido, outros não, como ocorre com as línguas neolatinas.

O latim vulgar, que dominou diversos grupos de idiomas diferentes na Europa, deu origem a diferentes línguas românicas. Ele mesmo reflete influências oriundas de outras línguas como o grego devido ao contato e a importância filosófica e literária que teve esta língua na época Antiga. Em português, inúmeras palavras usadas no nosso dia-a-dia revelam um contato antigo entre essas duas línguas: o grego e o latim. Palavras ou raízes gregas estão bastante presentes não apenas em línguas neo-latinas. O português e o italiano compartilham vários empréstimos mantendo sua forma gráfica e seu conceito, alguns deles são compartilhados também com o francês (latino) e o inglês (germânico ocidental):

Em francês: 'pharmacie', 'philosophie', 'épique', 'dilemme', 'éphemère', 'empathie', 'énigme'.

Em inglês: 'pharmacy', 'philosophy', 'epic', 'dilemma', 'ephemeral', 'empathy', 'enigma'.

Em italiano: 'farmacia', 'filosofia', 'epico', 'dilemma', 'effimero', 'empatia', 'enigma'.

Em português: 'farmácia', 'filosofia', 'épico', 'dilema', 'efêmero', 'empatia', 'enigma'.

O termo 'farmácia', que designa 'local onde se vende remédio' é originário do grego. Vemos que o conceito de 'farmácia' toma formas diversas em línguas diferentes como em português e em alemão, língua na qual é a ideia de estabelecimento que veicula, enquanto que em português é o seu conteúdo, «a droga» que se cristalizou:

Em alemão: apotheke, oriundo do baixo latim apotheca, derivado do grego apothéke 'loja'.

Em português: 'farmácia', oriundo do grego pharmakon 'veneno', 'droga'30.

Às vezes, um mesmo conceito, 'aquele que pode curar', é expresso por duas palavras diferentes em uma mesma língua:

1. Nos Estados-Unidos da América e na Grã Bretanha usam termos diferentes para 'médico':

Em inglês estado-unidense: 'physician'.

Em inglês britânico: 'doctor'.

2. O francês conhece dois termos para 'médico' usados em épocas diferentes :

Em francês da idade média: 'physicien'31.

Em francês contemporâneo: 'médecin'322.

30. O português antigo usava o termo 'botica', que vem do grego apotheke.

31. A palavra fisico expressa em latim 'aquilo que se relaciona com a natureza'.

32. No francês coloquial, 'toubib', uso bastante corrente, provém do árabe tebîb ou tbib, designando 'feiticeiro', hoje em dia 'médico'. 
Esses exemplos mostram que em línguas de uma mesma família linguística pode haver uma variedade de palavras que revelam uma origem comum. Elas podem ter uma mesma pronúncia como 'casa' em português e em italiano, com uma mesma escrita, ou apresentam uma pequena diferença fonética, como 'casa' em português [kaza] e em espanhol [kasa], permitindo observar a evolução da fonética: fricativa sonora em português /z/ e fricativa surda em espanhol $/ \mathrm{s} / 33$. Uma mesma palavra pode apresentar uma mesma realização fonética, porém com grafias diferentes. Vejamos a palavra homem em português que se grafa homme em francês, vomo em italiano e hombre em espanhol, todas oriundas do latim homo, revelando um parentesco linguístico. Neste parentesco, há palavras usadas em uma língua como 'vagabundo' em português e em italiano 'vagabondo', mas em desuso em francês, 'vagabond' - que, quando usada, remete a um nível castiço da língua ou ao francês antigo. Já em espanhol, esse sentido é dado pela palavra 'flojo'. Dentro do âmbito de empréstimos linguístico, uma determinada palavra em uma língua como lunch em inglês que significa 'almoço', pode entrar no campo lexical de outra língua com um sentido diferente. Em português, lunch, dito e escrito 'lanche' significar 'merenda'. A palavra verbal réaliser, em francês, entrou no inglês com o sentido de 'percerber', (to) realize 'fazer algo' e voltou para o francês com o sentido usado pelos anglosaxãos: "Je réalise que tu es déjà arrivé» (francês)| «Eu me dei conta que você já chegou». Hoje os dois sentidos da palavra são usados em francês: «ll a réalisé un beau travail» | «Ele fez um bom trabalho»! Muitos falantes franceses são conscientes que o sentido de «perceber» vem do inglês, mas a nova geração já não faz a diferença e o uso do sentido inglês passou a ser bastante produtivo.

\subsection{Palavras de origem indígena enriquecendo outros horizontes lexicais}

O sistema lexical do português do Brasil dispõe de muitas palavras provenientes de línguas indígenas. 'Pajé' é uma delas. Ela deriva da família linguística tupi-guarani, $p a$ 'ye, designando 'aquele que tem atributos de 'curar', de 'negociar com entidades humanas e entidades (espirituais) não humanas' ou ainda de 'ajudar' ou de 'usar malefícios'. Esta palavra encontra-se em aparai 'pyaxi' e em wayana 'pïjai' com os mesmos atributos semânticos.

Vimos acima como as palavras viajam de uma língua a outra, variando de forma e de sentido de uma língua a outra. O mesmo ocorre com línguas indígenas; as palavras de uma língua são encontradas em outras da mesma família linguística ou em outras famílias linguísticas indígenas ou também não indígenas. Tomemos três exemplos: anta (o maior mamífero amazônico); ananas (fruta) e sumaúma (uma das maiores árvores da Amazônia).

Exemplo 1: a palavra «anta» (tapirus terrestris em diferentes línguas
$\begin{array}{ll}\text { Em tupinamba: } & \text { tapi?ír } \\ \text { Em wayampi (tupi-guarani): } & \text { tapi'i } \\ \text { Em francês: } & \text { tapir } \\ \text { Em aparai (caribe): } & \text { maxipuri } \\ \text { Em wayana (caribe): } & \text { maipuli } \\ \text { Em palicur (arauaque): } & \text { arudiki } \\ \text { Em português: } & \text { anta (do árabe andalus 'lamta') }\end{array}$

33. O latim dispunha de dois termos para designar 'casa': domus, 'a morada do senhor com poderes' e casa 'choça', 'cabana', 'habitação simplória'. Essa segunda designação permaneceu em algumas linguas neolatinas (português, espanhol, italiano, romeno, para designar 'habitação' sem a conotação de baixa qualidade. O termo domus é encontrado em russo, 'dom'. 
Duas línguas tupi-guarani e o francês empregam a palavra 'tapi'i(r)' para designar a 'anta'. Este nome em português pode provir do latim antae 'construção megalítica prehistórica'. Ter o nome do mamífero designado por tal palavra pode ter sido por comparação à sua corpulência que lembra um dolmém. $O$ aparai e o wayana dispõem de uma mesma palavra para designar 'anta'.

As línguas indígenas wayampi (tupi-guarani), aparai e wayana (caribe), o francês e o português (latina) empregam uma mesma palavra originária do tupi-guarani, com variação fonética, para designar a fruta 'ananas', ou 'abacaxi'.

\begin{tabular}{|c|c|}
\hline Em wayampi: & nãnã \\
\hline Em aparai, wayana: & nana \\
\hline Em palicur: & kawah \\
\hline Em français: & ananas \\
\hline Em português: & ananas \\
\hline Em inglês: & pineapple \\
\hline Em espanhol: & piña \\
\hline
\end{tabular}

O aparai e o wayana (caribe) e o wayampi (tupi-guarani) compartilham um mesmo termo para a árvore sumaúma: kumaka (Ceiba pentandra (L.) Gaerth.):

Exemplo 3: a palavra «sumaúma» (Ceiba pentandra (L.) Gaerth.) em diferentes línguas

$\begin{array}{ll}\text { Em wayampi: } & \text { kumaka } \\ \text { Em wayana: } & \text { kumaka } \\ \text { Em aparai: } & \text { kumaka } \\ \text { Em alucu: } & \text { kãkãtri } \\ \text { Em francês: } & \text { fromager } \\ \text { Em português: } & \text { sumaúma }\end{array}$

O aparai e o wayana compartilham uma parte do vocabulário de suas línguas nos mesmos moldes apontados acima sobre a influência do grego e no latim nas línguas neolatinas e em outras famílias linguísticas. A imensa diferença é que sabemos a origem das línguas românicas e de muitas influências no latim pelo grego. Isso se deve à escrita, aos escritos históricos, o que permitiu aos filólogos entenderem o processo da evolução lexical, morfológica e também o parentesco entre elas, chegando à uma origem comum das línguas. No caso das línguas indígenas, nem sempre é possível encontrar a etimologia das palavras.

A amostra de empréstimos lexicais acima expõe o vasto campo geográfico pelo qual as palavras podem circular. Novos conceitos, novas ferramentas, novos materiais entram nas mais diversas línguas. Os empréstimos ajudam a retraçar contatos que um povo teve ou pode ter tido direto ou indiretamente dentro de uma mesma família linguística ou em famílias distintas. Os aparais e os wayanas não fogem à regra; eles emprestaram e emprestam palavras dos povos com quem têm contato, povos indígenas ou não - como todos povos, como todas as línguas.

34. Para os nomes autoctones ver Grenand et al. (2004). 


\subsection{Empréstimos linguísticos trilhando a história do contato}

A linguística histórica estuda o processo de desenvolvimento de uma língua, buscando compreender, ao longo do tempo, as mudanças ocorridas em sua estrutura e uso, e as razões das mudanças. A partir de empréstimos linguísticos, a lexicografia aparai e wayana permite identificar novos lexemas relativos a produtos europeus, como 'ferramentas', 'armas', 'tecidos' trocados por produtos manufaturados indígenas, como redes. As palavras alakapuha 'espingarda' vem de 'arcabusa' e kamisa ${ }^{35}$ entrou com o sentido de 'pano', 'tecido'. De onde vêm esses termos? Armas e tecidos eram provavelmente negociados por mercadores marítimos presentes no litoral atlântico guianês desde os séculos XVI-XVIII, à busca do «El Dorado» ${ }^{36}$. Os afro-guianeses foram intermediários nas trocas de mercadorias entre colonos europeus e povos indígenas. Os wayampis, por exemplo, foram controladores do comércio da área do Oiapoque entre 1850 e 1880 (GRENAND, 1982, p. 182). Crevaux (1883, p. 128), por sua vez, nota que desse contato de transporte e de aquisição de mercadorias, os wayanas viram que estar em contato com os wayampis e os alucus ${ }^{37}$ seria um meio de obter os objetos ocidentais. A partir de 188991, a posição dos wayanas nos contatos com outras etnias se inverteu: eles passaram de 'compradores de mercadorias' a 'fornecedores' e traziam para o interior das terras mercadorias diversas ${ }^{38}$, objetos que conseguiam com os afro-guianeses do Suriname (GRENAND, 1982, p. 183). Não se sabe quando palavra para 'dinheiro' entrou no vocabulário das línguas indígenas dessa região guianesa, mas elas dispõem de um mesmo vocábulo, kalakuli| karakuri em wayana, aparai (caribe) e wayampi39 (tupiguarani) ou ainda karukri em palicur (aruaque), que provavelmente entrou por meio de uma das línguas crioulas dos afro-guianese ${ }^{40}$, com quem o contato comercial era feito. $O$ termo era conhecido desses povos, mas nada nos diz se usavam dinheiro. Quando wayanas e aparais trabalhavam como caçadores de pele (de onça), coletores de balata no baixo rio Paru eram pagos com material de consumo, entre eles espingardas. Não nos mencionam terem tido seus trabalhos pagos com dinheiro ${ }^{41}$. Na Guiana Francesa testemunhos orais wayanas e aparais contam que passaram a receber dinheiro nos anos $1950^{42}$, até então, o trabalho ou a aquisição de mercadorias eram feitas por meio de troca.

35. O termo kamisa designa em aparai e em wayana tangas masculina e feminina, feitas de algodão vermelho.

36. As Guianas tinham sido atribuídas aos espanhóis pelo tratado de Tordesilhas em 1494, mas estes as desprezaram por serem menos interessantes que o Peru ou o México para o ouro. Porém, no século XVIII (1775), os espanhóis se fazem presentes na região guianesa buscando o «El Dorado». (SOUTY, 1986, p. 310). Vale lembrar que o primeiro europeu a chegar no rio Amazonas, na foz da ilha de Marajó, foi Vicnte Yañez Pinzón em 1499.

37. Citado por Crevaux como Boni, nome de uma grande liderança alucu.

38. Do Suriname levavam « tecido para mosquiteiro, malas ou baus metálicos, gamelas, miçangas de vidro, facas, anzois, louça esmaltada, enxó para cavar canoa e produtos de colheita como goma de caucho e castanha do Pará ou ainda artesanato como rede em fio. Dos Wayampis eles compravam cão de caça adestrado, novelos de fio de algodão, pacotes de tabaco, redes tecidas e penas » (trad. Adaptada por E. Camargo). (GRENAND, 1982, p. 183).

39. Os wayampis, originários da bacia do rio Paraná, viviam no Médio rio Xingu, donde migraram para o Baixo rio Jari, no século XVIII. (GRENAND, 1982, p. 183)..

40. É oportuno lembrar que no século 18, não havia moeda corrente na Amazônia, sendo o Sistema de troca a "moeda corrente".

41. Termo que não provém nem do alucu nem do sranan tongo. Fr. Grenand (1989) propõe uma origem do kali'na designando 'tudo o que brilha'.

42. Jean-Marcel Hurault, geógrafo e etnógrafo, que teve como missão colocar 7 marcos de concreto para marcar a fronteira seca entre o Brasil e a Guiana, pagava com produtos industrializados e também em dinheiro os indígenas e afro-guianeses que colaboravam com ele. 
Esses dados históricos facilitam a compreender a presenca de palavras de diferentes línguas em distintas línguas da região. Adiante (3.5.), os dados mostram algumas palavras que entraram no léxico aparai e wayana por intermédio de línguas crioulas dos afro-guianeses, referindo-se a produtos mercantis. Já o léxico entre línguas indígenas de famílias linguísticas diferentes refere-se sobretudo à fauna (peixe, aves, animal de caça), e também a artefatos que parecem sugerir material usado no comércio (3.4.). De qualquer forma, os wayanas e os alucus na Guiana Francesa estão ainda hoje em contato permanente, e a relação de 'troca' se mantém, porém, hoje, o que antes o wayana pagava com rede, cães de caça, arcos e flechas, hoje ele paga com dinheiro. Os alucus continuam levando bens de consumo como mascates (mercador ambulante), e palavras dessa língua continua entrando no wayana, mesmo em uma produtividade bem menor que há apenas trinta anos atrás.

\subsection{Compartilhando vocábulos}

Convivendo entre si pelo menos por duzentos anos, o contato entre os aparais e os wayanas revela simbioses e osmoses ${ }^{43}$ sociolinguísticas tanto no nível social, como na fusão em algumas das práticas socioculturais; o rito de purificação (epurutopo, em aparai, e eputop, em wayana) ou a assimilação de práticas culturais: conhecimento da manufatura de algodão pelos aparais, objetos (redes, porta-bebê) adotado pelos wayanas. Essas duas línguas compartilham muitos lexemas.

\section{Vocábulos idênticos}

Abaixo, observa-se palavras idênticas em aparai e em wayana expressando o mesmo significado.

\section{Exemplo 4-vocábulos idênticos}

$\begin{array}{ll} & \text { aparai|wayana } \\ \text { Árvore, bastão, pau } & \text { wewe } \\ \text { Basta, suficiente } & \text { epo } \\ \text { Buzina de cabaça grande } & \text { kuhku. Imita coruja grande sp. } \\ \text { Flecha ponta de madeira } & \text { kamata. Usada para matar pássaro. } \\ \text { Lontra } & \text { awawa } \\ \text { Macaco prego } & \text { meku } \\ \text { Ovo } & \text { ihmo }^{44} \\ \text { Remo } & \text { apukuita } \\ \text { Vasilhame de cuia } & \\ \end{array}$

Muitas vezes parece haver vocábulos diferentes entre elas, mas trata-se, no entanto, de uma mesma palavra: o alfabeto wayana segue o seu sistema fonológico ao passo que o aparai dispõe de um alfabeto semi-fonético semi-fonológico, o que faz com que o alofone seja indicado por uma letra. A lateral retroflexa [ l] é grafada 'r' em aparai e 'l' em wayana, a pronúncia e o significado são um só:

43. Cf. Cáccamo, Celso Alvarez (2004).

44. O wayana dispõe de um lexema pleno para 'ovo' pumo usado como determinante de nome: kulasi pumo 'ovo de galinha', e ihmo é sua forma lexical irregular para a $3^{\text {a }}$. pessoa do possessive $i-h m o / 3^{\text {a }}$.POSS-ovo/ 'seu ovo'. O aparai não dispõe do termo pleno pumo.

45. Akupuita, no wayana falado na Guiana Francesa, apresenta uma metatese segmental.

46. Guardar farinha, pimenta, mel, bebida, larvas de palmeira. 


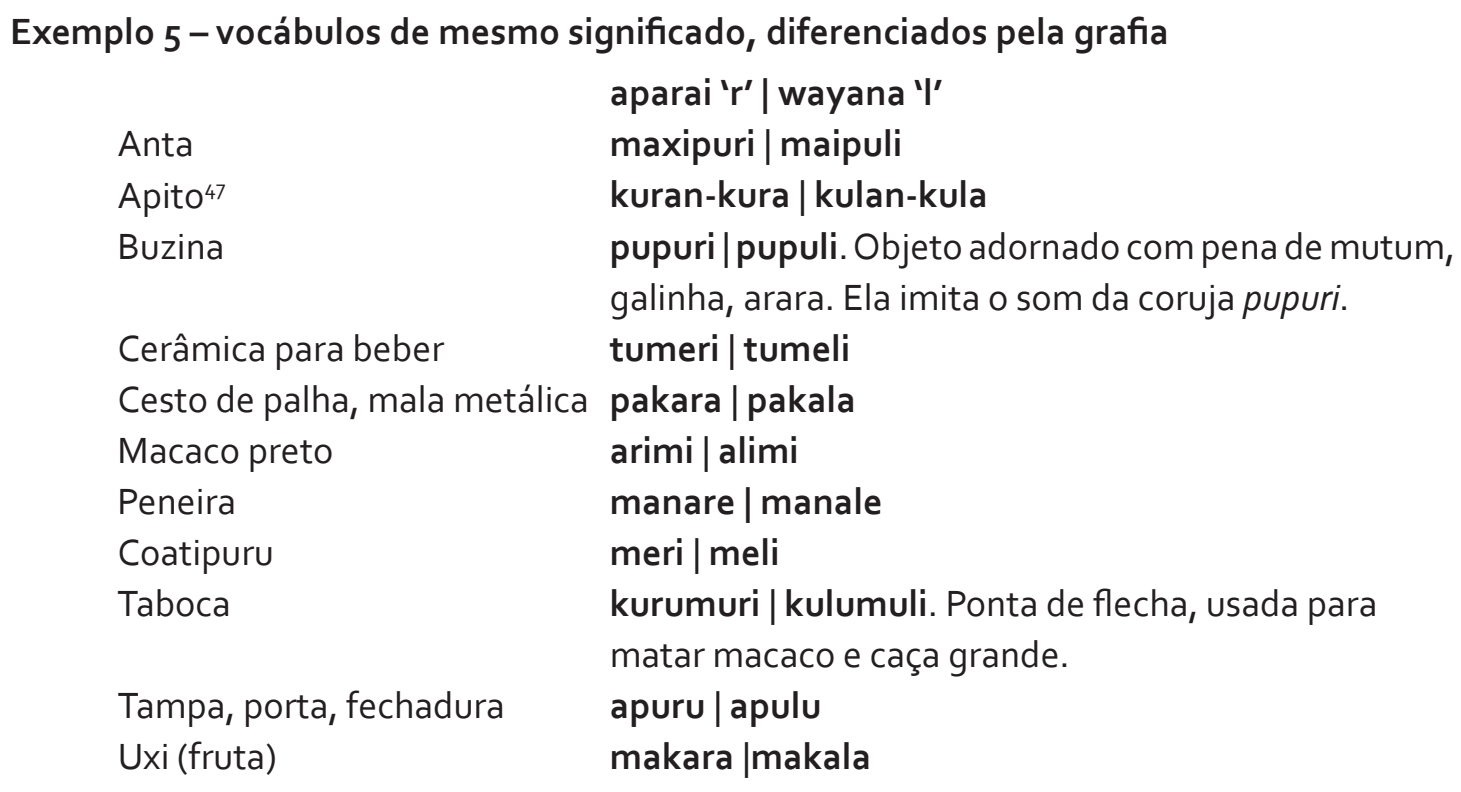

Muitas palavras escritas com 's' em aparai, são escritas com ' $h$ ' em wayana. Esta manteve o uso dos dois segmentos quando a fricativa /s/ é seguida da vogal/u/:

Exemplo 6 - vocábulos de mesmo significado, diferenciados pela grafia

$\begin{array}{ll} & \text { aparai 's' | wayana ' } h \text { ' } \\ \text { Caxiri branco (bebida) } & \text { sakura | hakula } \\ \text { Cesto, guarda pimenta } & \text { sumuri | sumuli, humuli } \\ \text { Seio, leite } & \text { susu | susu, huhu }\end{array}$

Em alguns casos, a vogal final da palavra wayana cai no seu uso não derivacional, o que não ocorre no aparai:

Exemplo 7-vocábulos de mesmo significado com queda vocálica em wayana
$\begin{array}{ll}\text { aparai } \mid \text { wayana } \\ \text { tymanakemy } \mid \text { tïmanatkem }\{i\}, \\ \text { sustentada por } 8 \text { esteiros }\end{array}$
$\begin{array}{ll}\text { Abrigo no mato } & \text { meikoropano } \mid \text { meikolopan }{ }^{48} \\ \text { Esposa de } & \text {-pyty } \mid \text {-pït }\{1\} \\ \text { Cocar, máscara oroko } & \text { oroko } \mid \text { olok }\{0\}\end{array}$

Em wayana, a vogal final elidida, indicada entre parênteses, reaparece em processo derivacional:

\section{Exemplo 8 - vocábulo wayana com vogal final presente em processo derivacional \\ Não tem máscara orok\{o\}. Olokomna man. \\ Deu à esposa dele, ipit\{1\} Ipïtịja tëkalëi. \\ Não tem uma casa sobrado tïmanatkem\{̂\}. Tïmanatkemïmna man.}

47. Cerol de abelha e pena.

48. Termo derivado provavelmente de uma língua afro-guianesa. Talvez construção de uma dessas línguas faladas entre a Guiana Francesa e o Suriname e em seguida copiada pelos indígenas da região. 
O fonema aproximante labial /w/ grafado "w" em wayana não existe em aparai:

\begin{tabular}{ll}
\multicolumn{1}{l}{ Exemplo 9-ausência da aproximante /w/ em aparai } \\
& aparai | wayana \\
Açaí & apu |wapu \\
Grupo wayana & ajana | wajana \\
Pica-pau & etu | wetu \\
Roda de teto & maruana | maluwana
\end{tabular}

Em aparai, a fricativa coronal sonora /z/ corresponde a fricativa palatal /j/ em wayana, apesar de /j/ existir em aparai:

Exemplo 10 - correspondência entre /z/ em aparai e /j/ em wayana
$\begin{array}{ll}\text { aparai | wayana } \\ \text { zanga masculina } & \text { zara } \mid \text { jala } \\ \text { Moquém } & \text { zata } \mid \text { jata } \\ \text { Coatipuru } & \text { zao } \mid \text { jau } \\ \text { Posposição locativa } & \text { zukini } \mid \text { jukini } \\ \text { Lontra pequena } & \text { joroko } \mid \text { jolok }\{0\} \\ \text { Entidade yoroko } & \text { a }\end{array}$

A vogal «ë» em wayana corresponde a «o» em aparai, visto não haver nesta língua a vogal central média:

Exemplo 11 - correspondência entre /o/ em aparai e /ë/ em wayana

$\begin{array}{ll}\text { Argila } & \text { aparai | wayana } \\ \text { Caba, vespa } & \text { orino | ëlinë } \\ \text { okomo | okomë } \\ \text { okoi | ëkëi } \\ \text { Forno (de barro ou de ferro) } & \text { orinato | ëlinat\{1\} } \\ \text { Remédio vegetal } & \text { opi | ëpi } \\ \text { Abelha, mela } & \text { ano | wanë }\end{array}$

O aparai tem vogal longa, anotada aqui por dupla vogal, ao passo que a duração é indicada por ' $h$ ' ou simplesmente não é grafada:

\[ \begin{array}{l}\text { Exemplo 12 - duração vocálica } \\ \text { aparai | wayana }\end{array} \]
$\begin{array}{ll}\text { Arpão (para pesca) } & \text { paamta | pamta } \\ \text { Parceiro estrangeiro } & \text { Maana | pawana (relação de aliança potencial) } \\ \text { Nome próprio } & \text { Maanpe }{ }^{49} \text { Manpe }\end{array}$

A duração vocálica é pouco produtiva em wayana. Ela aparece em poucos vocábulos, como em maa 'Pois bem,', puupu 'tracajá', tiïkë 'Faça!'

49. Os aparai escrevem manpe, e ao pronunciar a realização da duração vocálica é claramente perceptível. 


\title{
3.4. Vocábulos provenientes de outras línguas indígenas
}

As relações com outros grupos da mesma família linguística (tiriós, da família caribe) ou de famílias diferentes (wayampi e teco da família tupi-guarani) também aparecem no inventário lexical do aparai e do wayana. Alguns wayanas identificam vocábulos tiriós:

\author{
Exemplo 13 - vocábulo de origem tirió (caribe) \\ Arpão suparari | supalali. Ponta de arpão ou de flecha, feita \\ de ferro ou de madeira. Usado para matar pássaro, \\ caça. \\ Cabana \\ maita (way)
}

Aparais e wayanas compartilham alguns vocábulos de origem tupi-guarani.

Exemplo 14 - vocábulo de origem teco ou alguma língua tupi
$\begin{array}{ll}\text { aparai | wayana } \\ \text { Brasileiro } & \text { akuiwi | akuli } \\ \text { Cotia } & \text { paku | paku } \\ \text { Peixe pacu } & \text { surui | hului } \\ \text { Peixe surubim } & \text { palapi (way) } \\ \text { Prato } & \text { parana | palana } \\ \text { Rio grande, mar } & \end{array}$

A língua aparai dispõe de palavras de origem tupi-guarani não usadas em wayana:

$\begin{array}{ll}\text { Exemplo 15- vocábulo de origem } & \text { tupi (nhengatu[?]) na língua aparai } \\ \text { Boto } & \text { putu } \\ \text { Camarão pitu } & \text { pitu 'peixinho', 'piaba' } \\ \text { Casa } & \text { tapyi. Do tupi tapi'ri 'choupana'. } \\ \text { Jacaré } & \text { zakare } \\ \text { Louro, papagaio } & \text { roro 'cobra papagaio' } \\ \text { Macaxeira } & \text { makaxira } \\ \text { Peixe pirarara } & \text { piarara } \\ \text { Peixe pirarucu } & \text { piraruku } \\ \text { Peixe tucunaré } & \text { tukunare } \\ \text { Remo } & \text { apukuita. Do wayampi ypykwita (?) } \\ \text { Tipiti } & \text { matapi }\end{array}$

* Tipiti é o nome tupi para o cesto cilíndrico usado para espremer a massa da mandioca ralada, chamado em wayana de tïnkiï, ou kïnkiï. Os aparais preferiram adotar o nome tupi, matapi, para covo côncavo, para os que são alongados, os quais provém da armadilha cilíndrica para pegar crustáceo do rio, muito

50. De karai 'grande pajé' em tupi no séculoXVI, designando em seguida 'português; espanhol' no século XVII (Fr. GRENAND, 1989); 'senhor' em guarani, Cf. https://historiaeculturaguarani.org/a-morada-dos-karai/

51. O wayampi vivia perto de /palana/ palavra que recobre para os Tupis tanto o Amazonas como grandes rios assimilados ao oceano. (GRENAND, 1982, p. 80). Em um manuscrito, sem data, Grenand, cita Nimuendaju (1926) que indica que os wayampis viveram na bacia do rio Paraná. 
usado na Amazônia. O uso desse termo tupi para tipiti pode ser um índice de que os aparai não usavam esse utensílio. Qual seria a razão de terem adotado um nome tupi que designa uma armadilha de pesca? Pela sua forma? Pelo material usado na confecção? É interessante ver que entre esses vocábulos, há nomes de peixe. Qual razão levaria esses grupos que vivem hoje à beira de grandes rios ter em seu léxico nomes de peixes de origem tupi? Os wayanas viviam mata adentro (MORGADO, 1994), mas, já pelo menos há um século, transitam pelo rio Paru, onde pescam surubim, pacu. Os aparais viviam próximo ao rio Amazonas, na área dos rios Maicuru e Curuá do Norte, onde também há esses peixes. O roedor 'cotia' consome mandioca nos roçados, qual seria a razão de os wayanas e os aparais terem em seu léxico o nome desse roedor provindo de uma língua tupi-guarani, o que nos leva a seguinte indagação: será que não consumiam mandioca nem macaxeira?

No Baixo Amazonas houve missões dos capuchinhos e uma hipótese a se fazer quanto a presença importante de vocábulos de origem tupi na língua aparai seria que o grupo tivesse tivo contato com a língua geral usada nas missões. Os missionários capuchinos já estavam na região no final do século XVII (entre 1692-1693) com as fundações das missões de Pauxís e do Curuá. Os capuchinos do Curuá promoveram o deslocamento de Barés (aruaques) e de outras etnias do rio Trombetas para a missão do Surubiú, dando origem à atual cidade de Alenquer. Os aparais viviam nesta área (nos rios Maicuru e Curuá) onde houve missões. A figura 1 ilustra o número de missões existentes no norte do Brasil no século XVII e início do século XVIII, época da tupinização dos tapuias, o que dá sustento à hipótese de que introdução de vocábulos de origem tupi na língua aparai pode vir de um contato com uma ou mais missões, ou simplesmente devido o ocorido ao longo do período colonial, o uso da «língua Geral da Amazônia (LGA)52» como língua de comunicação interna da Amazônia53.

Figura 1 - Mapa das Missões no Norte do Brasil

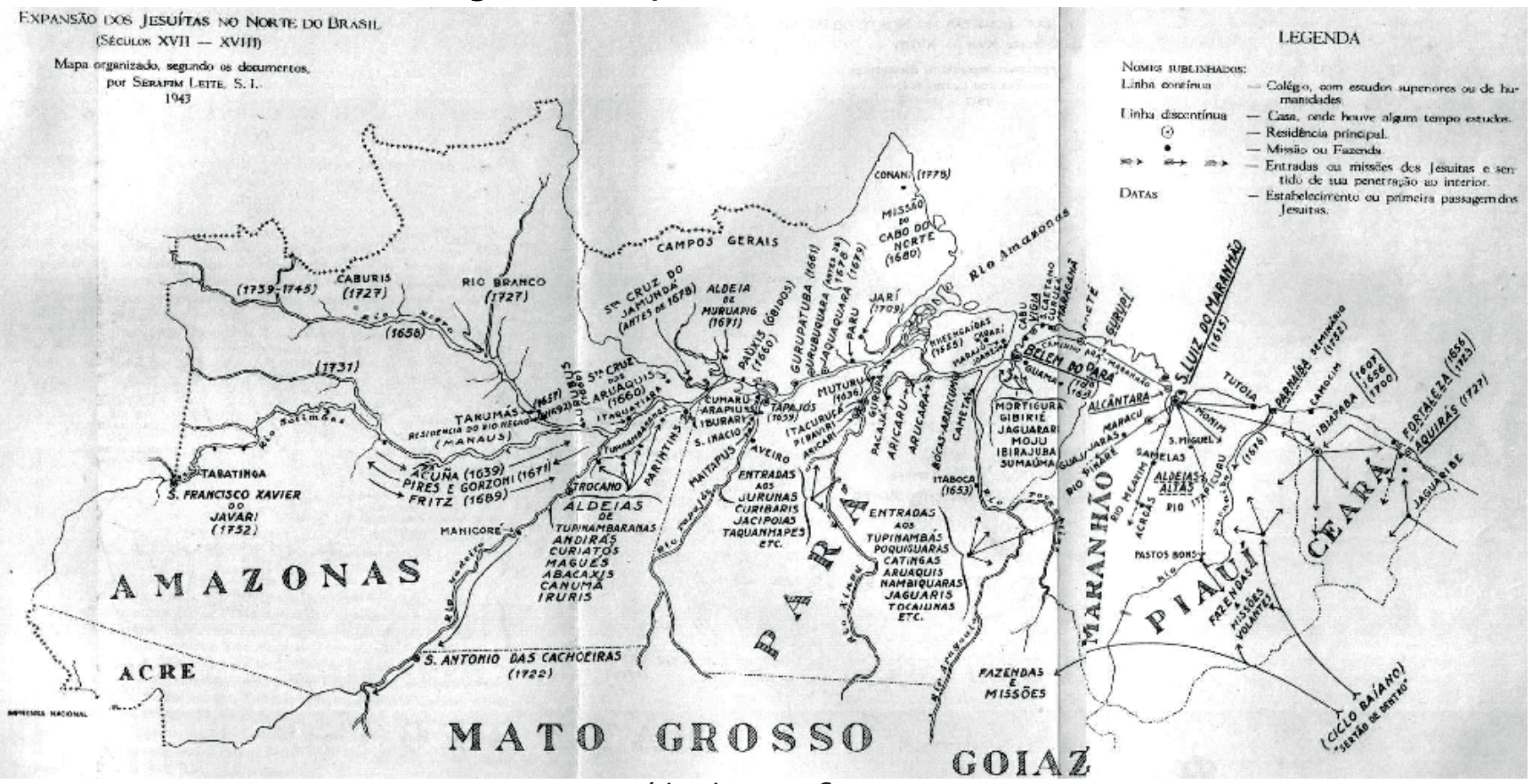

Mapa extraído de Serafim Leite 1943.

52. Língua geral, desenvolvida pelos jesuítas nos séculos XVI e XVII com base no vocabulário de línguas tupi-guaranis faladas no litoral atlântico.

53. Cf. Freire Bessa (2003, p. 34). 
Os grupos indígenas (caribes, arauaques) dessa região guianesa também tiveram contato com os wayampis (da família tupi-guarani). Os inúmeros conflitos entre eles não impediram as relações de aliança entre wayampi e wayana, por exemplo, marcando «tratados de paz» entre eles. Relações interétnicas permitiram o empréstimo de vocábulos dessas línguas em contato, como vemos em palicur (família arauaque) alguns termos de origem caribe:

\section{Exemplo 17 - termos de línguas caribes em palicur}

$\begin{array}{llll} & \text { palicur } & \text { aparai } & \text { wayana } \\ \text { algodão } & \text { mawru } & \text { mauru } & \text { mawu } \\ \text { fava, feijão } & \text { kumat } & \text { kumata } & \text { kumata }\end{array}$

\subsection{Vocábulos provenientes de línguas não indígenas}

Com o contato de grupos indígenas com seus intermediários afro-guianeses para a aquisição de bens industrializados, palavras que designam as ferramentas adquiridas nas línguas crioulas dos afro-guianês entraram no vocabulário do aparai e wayana. Esse contato deixou não apenas inúmeras palavras no vocabulário dessas línguas indígenas, revelando o tipo de mercadoria usada na troca, mas também a origem da mercadoria. No exemplo 18, pode-se ver um vocábulo de origem inglesa. O aparai e o wayana não dispõe de oclusivas sonoras, o que leva os falantes adaptarem a palabra 'estrangeira' ao sistema fonológico de suas línguas, com exceção da palabra beli que revela ser um empréstimo recente, dentro de alguns anos provavelmente será pronunciado 'peli'. A lista de palavras abaixo sugere diferentes vias pelas quais as palavras entraram no sistema lexical do aparai e do wayana:

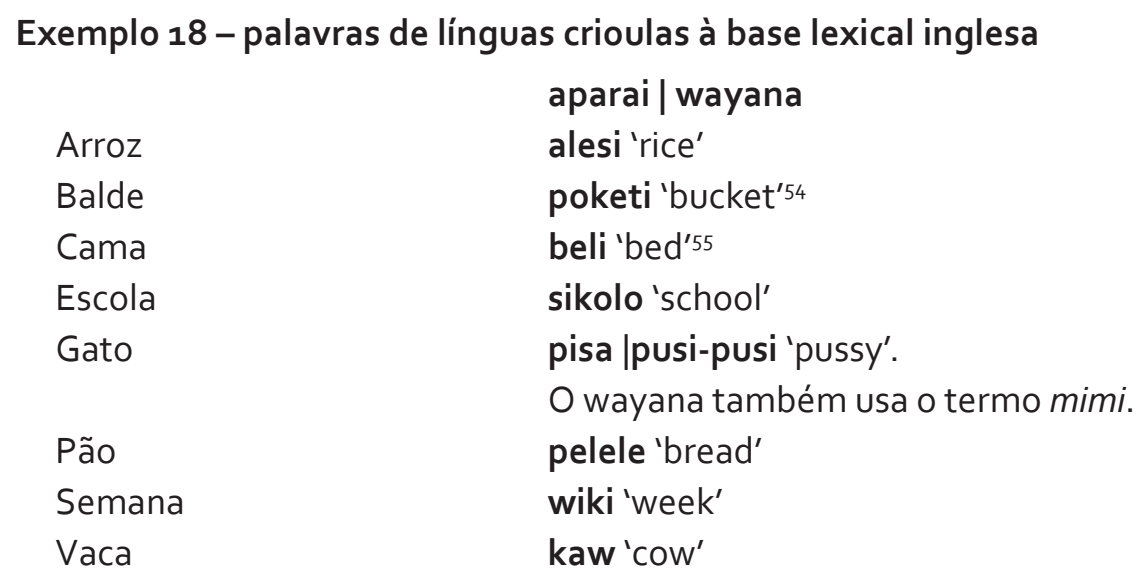

O amendoim okonehpy em aparai e ahnep em wayana mostram vocábulos de raiz caribe, porém o wayana falado na Guiana Francesa adotou o termo pinta do sranan tongo cujo uso se tornou produtivo, substituindo o termo original, este muitas vezes desconhecidos da nova geração.

Muitas palavras oriundas de línguas afro-guianesas faladas sobretudo no Suriname fazem hoje parte do vocabulário do wayana da Guiana Francesa, principalmente do alucu, com quem os wayanas mantêm contato constante:

54. Não havendo oclusivas sonoras nessas línguas caribes, o /b/ é interpretado ' $p$ '.

55. Não havendo 'd' no estoque de fonemas do wayana, /d/ é, por ora, interpretado 'l'.

Revista Brasileira de Línguas Indígenas - RBLI ISSN 2595-685X https://periodicos.unifap.br/index.php/linguasindigenas

Macapá, v. 3, n. 1, p. 27-55, 2020 


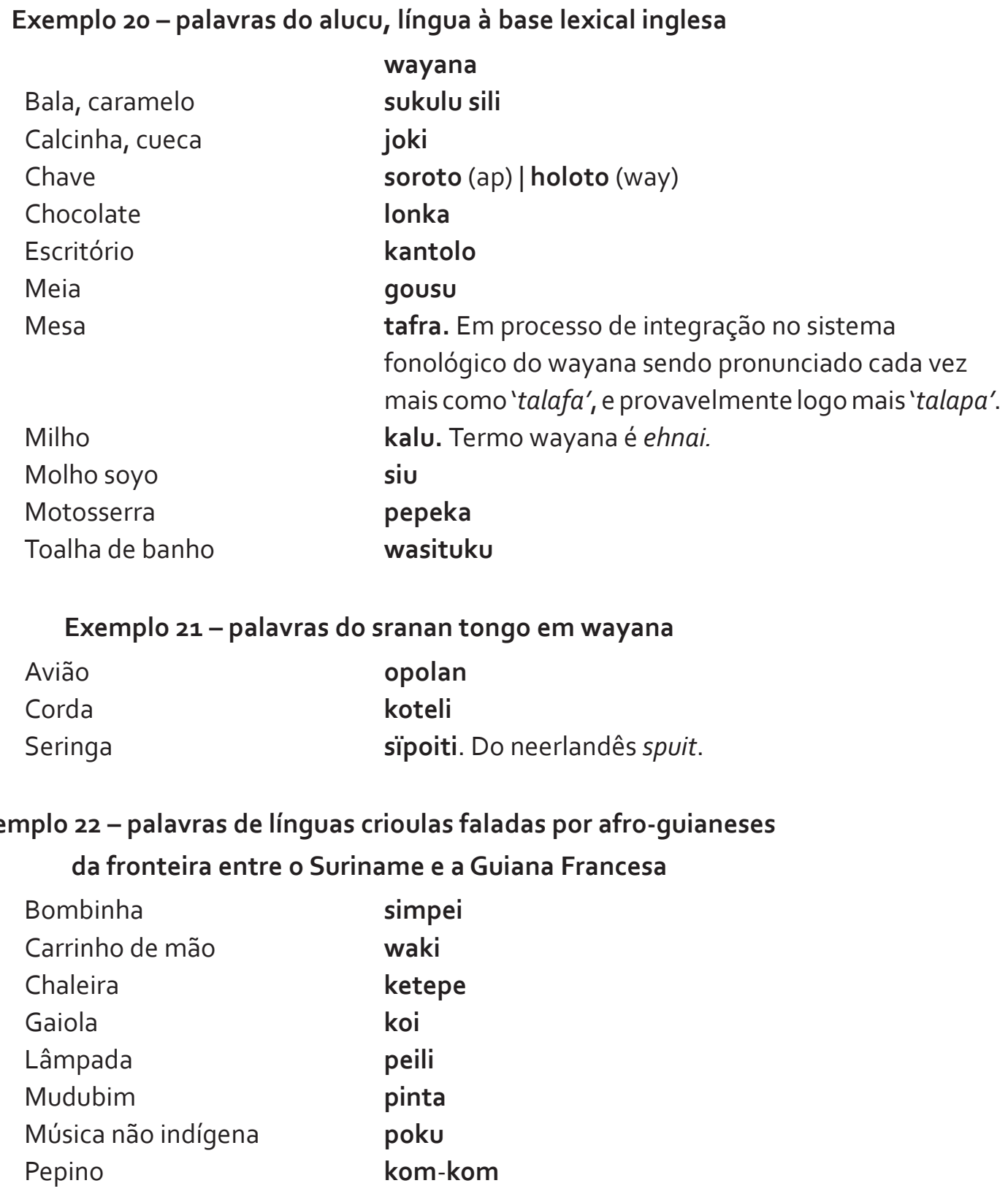

Abaixo algumas palavras do português em aparai e em wayana:

$\begin{array}{ll} & \text { Exemplo 23-palavras do português } \\ \text { Bacia } & \text { paxia, paxiha | pasika } \\ \text { Bucha } & \text { puxa | pusa } \\ \text { Francês } & \text { paraxixi | palasisi } \\ \text { Gasolina } & \text { kasurina | kasulin\{U\} } \\ \text { Miçanga } & \text { kasuru| kahulu } \\ \text { Sabão } & \text { sahpau |hapau, hapu } \\ \text { Saco plástico } & \text { saku| haku } \\ \text { Tuberculoso } & \text { mepekuroso | mepekuloko } \\ \text { Fósforo } & \text { palitu }\end{array}$


O aparai e o wayana dispõem de uma mesma palavra, patu, do português 'prato', mas empregam com significados diferentes.

Exemplo 24-palavra 'prato' do português
Panela
patu (way).
Prato
Provavelmente por ser prato fundo de alumínio.
patu (ap)

Para 'panela' o aparai usa a palavra oripo, e para 'prato' o wayana emprega ëlimak.

A palavra que designa 'carro' entrou em aparai como auto que pode provenir do francês, como ele entrou no vocabulário do wayana da Guiana Francesa oto. Já o wayana do Brasil optou kahu do português. Para 'motor' o aparai e o wayana emprestaram do português com realizações fonéticas diferentes, mutu, em aparai e montoru em wayana.

Muitas palavras do francês entraram no wayana por meio de línguas crioulas afro-guianesas:

\begin{tabular}{ll}
\multicolumn{2}{c}{ Exemplo 25- palavras do francês em wayana } \\
Boneca & $\begin{array}{l}\text { popiki. } \\
\text { Do francês poupée, passando pelo holandês 'pop'. } \\
\text { paluku. Do francês pantalon. } \\
\text { simisa. Do francês chemise, entrando em wayana } \\
\text { Camisa }\end{array}$ \\
com o sentido de 'roupa'. \\
kapitem\{u\}. Do francês 'capitaine'. Do latim \\
capitanu $(m)$ entrou em francês pelo espanhol, capitán \\
Fósforo & $\begin{array}{l}\text { alimet. De allumette. } \\
\text { hopu. De savon. }\end{array}$
\end{tabular}

O contato com franceses é secular, mas a entrada de léxico francês nessas duas línguas caribes aumentou nos últimos quinze anos, com a ida de jovens para estudar no litoral, sobretudo em Caiena, Kourou [kuru]:

\section{Exemplo 26 - palavras do francês moderno em wayana}

$\begin{array}{ll}\text { Carro } & \text { oto 'auto' } \\ \text { Célula } & \text { pohtap 'portable' } \\ \text { Cerveja } & \text { bili 'bière' } \\ \text { Euro } & \text { elo } \\ \text { Feijoada } & \text { kasulet 'cassoulet' } \\ \text { Garrafa } & \text { kutei 'bouteille' } \\ \text { Rádio } & \text { latjo } \\ \text { Vídeo, televisão } & \text { widejo 'vidéo' }\end{array}$

E palavras do nahuatl clássico, língua dos Aztecas, entraram no wayana pelo francês que por sua vez emprestou do castelhano: 


\section{Exemplo 27 - palavras do nahuatl pelo francês em wayana}

Feijão

Tomate aliko 'haricot'. Do nahuatl ayecohtli.

tomat. Do nahuatl tomatl ou tomohuac ${ }^{56}$.

\section{Neologismo para designar vocábulos técnicos}

Entre 2016 e 2019, uma equipe de aparais e wayanas (Brasil e Guiana) participou de um projeto de estudo de acervos audiovisuais, documentos históricos e coleções museológicas para criar e alimentar um portal digital multilíngue que por ora aparece em três línguas: wayana-aparai-francês (https:/l watau.fr/s/watau-fra/page/accueil). O portal se chama WATAU (wajana apalai tuwalon apëipotpï uhpak lit. Registro de saberes antigos dos wayanas e aparais). Para se ter as páginas em modelo word com as diferentes designações (inserir, revisão, colar, corpar eetc...) em aparai e em wayana, oficinas de metalinguagem informática foram organizadas na área indígena (Suwi-Suwi Min), mas também na cidade de Oiapoque, Caiena e Paris. A equipe de estudo adaptou muitas das palavras já existentes na língua vernacular como termo técnico57:

Exemplo 28 - termos informáticos correspondentes entre o wayana e o aparai

$\begin{array}{llll}\text { Português } & \text { Wayana } & \text { Aparai } & \text { Leitura literal } \\ \text { Aceitar } & \text { ëë katop } & \text { yn katopo } & \text { 'ter o acordo de', 'dizendo sim' } \\ \text { Bateria } & \text { ulu } & \text { zuru } & \text { 'beiju' (lit. 'o beiju de') } \\ \text { Cabo } & \text { ilakmatop ewa } & \text { eary } & \text { 'corda para inserir algo' (way.), 'corda' (ap.) } \\ \text { Salvar } & \text { apëipotop } & \text { apoipotopo } & \text { 'para mandar pegar' } \\ \text { Vírus } & \text { akï } & \text { akyry } & \text { 'parasita' }\end{array}$

Este projeto, conduziu a equipe a criar uma palavra para 'computador', ëpitea, neologismo que é um acrônimo, no qual cada letra da palavra tem um significado em wayana:

$\begin{array}{ll}\text { Ëhmelë } & =\text { tudo } \\ \text { Pohnëptën me } & =\text { para pensar, refletir } \\ \text { Itenkapamila } & =\text { sem esquecer } \\ \text { Tëweihem } & =\text { o que é necessário } \\ \text { Epohnëptop } & \text { = para a memória } \\ \text { Ajau } & =\text { dentro }\end{array}$

Ëpitea significa literalmente "aquilo que tem (dentro) tudo o que é necessário para memorizar e não esquecer." Termo ainda bastante novo, cujo uso ainda não é compartilhado por todos os wayanas. A aceitação coletiva do termo pode levar algum tempo, como ocorreu com o nome criado para designar dicionário "ëtapomi", criado durante uma "oficina de dicionário", em 2009. Os primeiros wayanas consultados sobre o que achavam desse neologismo não participantes acharam uma aberração por se tratar de uma palavra inexistente. Ninguém nada sugeriu algo de melhor. Com o passar do tempo, passaram a usá-la para comentar o dicionário que estava sendo elaborado. Dez anos mais tarde, ëtapomi

56. Em nahuatl, tom-atl, tomo huac significa 'água gorda': tom ohuac 'gordo', atl 'água' 57. Camargo e ali (2020). 
'dicionário' está presente no léxico wayana. Ëtapomi não é um acrônimo como watau ou ëpitea. Tratase de um processo derivacional em que ëtapo designa 'regrupar' e omi 'palavra. Fusionaram o encontro vocálico entre dois 'o': ëtapo-omi cuja leitura literal significa 'regrupamento de palavras'58.

Um dicionário aparai está sendo elaborado, mas por ora não houve nenhuma discussão coletiva sobre um nome mais profunda em aparai que por ora não dispõe de um termo para computador, por sinal nem para dicionário.

A lexicografia aparai e wayana entre empréstimos e neologismos mostra a entrada de lexemas de línguas variadas pertencendo a uma mesma família linguística indígena ou a outras famílias de línguas indígenas ou não indígenas (espanhol, francês, português). Entram pelo contato de linguas pelo viés do contato interétnico ou, como vimos, pelo comércio mercantil. No aparai e no wayana falado no Brasil, a influência lexical estrangeira vem, hoje em dia, do português. Na Guiana Francesa, além de continuar a ter influência das línguas dos afro-guianeses, os vocábulos são de base lexical inglesa, francesa ou ainda do crioulo guianês, que estão entrando por meio da nova geração em contato com centros urbanos.

\section{A lista de cem palavras de Swadesh}

Durante as oficinas de língua aparai e wayana, aproveitamos para traduzir em aparai e em wayana a lista de cem palavras estabelecida pelo linguista americano Morris Swadesh (1909-1967). Ele expunha que quase $14 \%$ das palavras básicas de uma língua são substituídas a cada mil anos e que as línguas dispõem de um vocabulário básico, que segundo ele, é comum a todos os idiomas de um mesmo grupo linguístico. Elaborou várias listas, a primeira com 225 significados, porém a mais comum é a divulgada em 1972 contendo cem itens. O autor elaborou essa lista com vocábulos de base, entendidos como sendo resistentes aos empréstimos, tendo como finalidade a comparação lexicoestatístico. Aplicamola em aparai e em wayana o que oferece a oportunidade de ver a proximidade de alguns dos termos e a diferença de outros. Em alguns casos, para um mesmo termo em português há mais de uma palavra em aparai ou em wayana. Vejamos alguns exemplos:

Vocábulo n 8 - advérbio de negação 'não'.

Em aparai, o advérbio de negação apresenta uma forma plena, morfema livre, arypyra, e uma forma curta, morfema dependente. O wayana dispõe de um morfema livre, uwa, de um sufixo de negação verbal e de uma posposição, tapek. Vejamos como eles são empregados.

Para o advérbio de negação, arypyra (ap.) e uwa (way.) significa tanto 'não', como 'nada', 'jamais' e 'nunca':

$$
\begin{aligned}
\text { Aparai: } & \text { - Omise mah? - Arypyra } \\
& \text { - Você está com fome? - Não }
\end{aligned}
$$

Wayana: -Ëwapëjep? - Uwa.

- Você está com fome? - Não.

A lista de Swadesh indica apenas o advérbio de negação, os participantes da oficina reagiram, no entanto, e forneceram outros contextos com o sentido de "negação" lembrando que o aparai apresenta duas variantes deste advérbio: uma forma longa, arypyra, outra curta, pyra:

58. Os wayanas da Guiana Francesa elaboram dois dicionários: um é analítico (Wajana omi jatëku|Wayana au Coeur des mots, 2020) e o outro é lexicográfico, em andamento. Ambos são bilingues wayana-francês. 
Arypyra, que significa 'não', 'nada', 'jamais', 'nunca', é usado de forma independente:

- Kuratirihmo aihpyry seh mano? - Arypyra.

Você quer ovo frito? - Não.

A forma de negação curta, pyra, aparece junto ao substantivo: Nohpo pyra Não é uma mulher.

adjetivo: Axin pyra aytoryke kaikuxi nesekano. Correu devagar e a onça o pegou;

verbo: Unsehpo onyhkoh pyra exiko. Não corte o cabelo.

O wayana também apresenta duas variantes de negação com formas distintas: o sufixo -la e a posposição tapek.

A forma de negação -la associa-se ao:

adjetivo: Aluku omi upipola $\mathrm{O}$ alucu não é difícil. (= a língua alucu)

verbo: Ëtupoma hela wai Eu não quero me vestir.

A forma posposicional, tapek, relaciona-se ao:

nome: Wekï tapek Não é da família.

pronome: Lome ïwu tapek Mas, não sou eu. (responsável por ter feito algo...)

advérbio: Hejelon tapek wai Eu não sou daqui. (= deste rio).

A pessoa associa a esta posposição: - ltapek mëklë. —Mëklë Não é ele. (Sim), é ele.

O wayana dispõe ainda de um 'privativo' -mna:

Okahpe wai. Tenho anzol. (lit. Estou no dispor anzol)

Okamna wai. Não tenho anzol. (lit. Estou desprovido de anzol.)

Vocábulos referentes ao corpo humano- nome genérico e nome específico ou possessivo.

A lista de Swadesh composta de um vocabulário de base resistente aos empréstimos pode se deparar com algumas complexidades próprias de cada língua. Ele foca o léxico, mas há línguas na qual a palavra não é formada apenas de sua raiz, devido a processos derivacionais que se impõem e diferenciam-se pela sua estrutura morfológica.

Em aparai e em wayana, a categoria de posse proporciona uma subdivisão dos nomes em ao menos três classes semânticas, estas diferenciadas pela estrutura morfológica de seus membros por nomes inalienavelmente possuídos, nomes alienávelmente possuídos, nomes não possuídos - fenômeno bastante produtivo em diferentes línguas indígenas. Essas duas línguas caribes diferenciam o nome genérico do nome possuído. O aparai marca morfologicamente a relação alienável (-nu) ou inalienável $(-r u)^{59}$ :

59. Em wayana, a relação de inalienabilidade é marcada somente com a negação. Cf. Petrolina (2005) e Camargo \& Wajana (2019). 


\section{Exemplo 29.}

$\begin{array}{llll}\text { Nome } & \begin{array}{l}\text { Português } \\ \text { genérico }\end{array} & \begin{array}{l}\text { Comentário } \\ \text { específico }\end{array} & \\ \text { Aparai } & \text { pupu } & \text { ipupuru } & \text { corpo (de) } \\ \text { Wayana } & \text { pupu } & \text { ipupu } & \end{array}$

Quando a sílaba inicial do termo possuído é um ataque nulo, ocorre o fenômeno de ablaut, que modifica a vogal. Em aparai, a vogal /o/ em oma 'mão' realiza-se /e/ na forma do possessivo emary 'mão de'. Em wayana, a vogal inicial/o/ realiza-se /a/ na forma do possessivo:

\section{Exemplo 30.}

$\begin{array}{llll}\text { Nome } & \text { Português } & \text { Comentário } & \\ \text { Aparai } & \text { oma } & \text { emary } & \text { mão (de) } \\ \text { Wayana } & \text { omo } & \text { amo } & \end{array}$

A lista de Swadesh foi enriquecida com dados suplementares do aparai e do wayana.

Quadro 1. Lista de vocábulo de M. Swadesh

\begin{tabular}{|l|l|l|}
\hline Português & Aparai & Wayana \\
\hline 1. eu & Ywy & Ïwu (Guiana Francesa); ïu (Brasil) \\
\hline 2. tu, você & Omoro & Ëmë \\
\hline $\begin{array}{l}\text { 3. nós } \\
\text { exclusivo : 1-2+3 } \\
\text { inclusivo : 1+2-3 }\end{array}$ & $\begin{array}{l}\text { Yna } \\
\text { Kumoro }\end{array}$ & $\begin{array}{l}\text { Emna } \\
\text { Kunmë }\end{array}$ \\
\hline $\begin{array}{l}\text { 4. 3a. p. do singular, ele/ela: } \\
\text { anafórico singular : } \\
\text { 3a. p. do plural, eles/elas: } \\
\text { anafórico plural: }\end{array}$ & $\begin{array}{l}\text { Ynoro } \\
\text { Ynaroro } \\
\text { Mokaro }\end{array}$ & $\begin{array}{l}\text { Inëlë } \\
\text { Mëklë } \\
\text { Inamolo } \\
\text { Mëkjam }\end{array}$ \\
\hline 5. este/a & Sero & Helë \\
\hline 6. quem & Onoky & Ënïk \\
\hline 7. o que & Oty & Ëtï \\
\hline $\begin{array}{l}\text { 8. não } \\
\text { Ary }\end{array}$ & Arypyra (advérbio). & Uwa (advérbio). \\
\hline 9. todo, todos & $\begin{array}{l}\text { Pyra (negação } \\
\text { nominal e verbal) }\end{array}$ & $\begin{array}{l}\text {-tapek (posposição 'negação não-verbal) } \\
\text {-la (negação verbal) }\end{array}$ \\
\hline 10. muitos & Ehmero & Ëhmelë \\
\hline 11. um & Tuhke, moino, itamuru me & Kole, mëwisnë/mëwihnë \\
\hline 12. dois & Toiro & Pëkënatpë \\
\hline 13. grande & Asakoro & Hakenë \\
\hline
\end{tabular}

6o. A realização fonética é fornecida para alguns lexemas do aparai para apontar a parada glottal (') que é bastante produtiva. A parade glotal também indica a vogal longa que não marcada na escrita dessa língua. Muitas vezes essa parada ou duração vocálica é indicada pelo grafema ' $h$ '. 


\begin{tabular}{|c|c|c|}
\hline 14. cumprido & Mosa [mo:'sa] & Kupime \\
\hline 15. pequeno, curto & Pitiko & Apsik \\
\hline 16. mulher & Nohpo & Wëlïi \\
\hline 17. homem (adulto) & Orutua & Eluwa \\
\hline 18. pessoa (individual) & Ahno & Wajana \\
\hline 19. peixe & Kana & Kaa (antigo), ka (moderno) \\
\hline 20. pássaro & Torono [to'rono] & Tolopït \\
\hline 21. cão (, onça) & Kaikuxi & Kaikui \\
\hline 22. piolho & Azamo [a'za:mo] & Ëjam \\
\hline $\begin{array}{l}\text { 23. árvore } \\
\text { Tronco (=corpo) }\end{array}$ & $\begin{array}{l}\text { Wewe } \\
\text { ipunu }\end{array}$ & $\begin{array}{l}\text { Wewe } \\
\text { Ipun }\end{array}$ \\
\hline 24. semente & Ipuhturu [i'puh:turu] & Eputpï \\
\hline $\begin{array}{l}\text { 25. folha } \\
\text { Folha de }\end{array}$ & $\begin{array}{l}\text { ary } \\
\text { zary }\end{array}$ & Ale \\
\hline $\begin{array}{l}\text { 26. raiz } \\
\text { raiz de }\end{array}$ & $\begin{array}{l}\text {-mity } \\
\text { imity }\end{array}$ & $\begin{array}{l}\operatorname{mit}\{1\} \\
\text { imit }\end{array}$ \\
\hline 27. casca (de árvore) & Wewe pihpyry & Wewe pitpë \\
\hline 28. pele & Pihpo [pih:po] & Pitpë \\
\hline $\begin{array}{l}\text { 29. carne, corpo } \\
\text { carne de, corpo de }\end{array}$ & $\begin{array}{l}\text { punu } \\
\text { ipunu }\end{array}$ & $\begin{array}{l}\text { punu } \\
\text { ipun }\end{array}$ \\
\hline 30. sangue & Munu & Mïwu \\
\hline $\begin{array}{l}\text { 31. osso } \\
\text { osso de }\end{array}$ & $\begin{array}{l}\text { Zepo [Ze:po] } \\
\text { zehpyry }\end{array}$ & $\begin{array}{l}\text { Jetpë } \\
\text { ljetpï }\end{array}$ \\
\hline $\begin{array}{l}\text { 32. gordura } \\
\text { gordura de }\end{array}$ & $\begin{array}{l}\text {-kase } \\
\text { ikasery }\end{array}$ & $\begin{array}{l}-k a t\{1\} \\
\text { lkat }\end{array}$ \\
\hline 33. ovo & Ihmo ['ihmo] & $\begin{array}{l}\text { Pumo (possessivo associado a um nome) } \\
\text { Ihmo (possessivo associado } \\
\text { a um pronome pessoal) }\end{array}$ \\
\hline 34. corno & Iretyry ['kapau iretyry] & Isikletï \\
\hline $\begin{array}{l}\text { 35. rabo } \\
\text { rabo de }\end{array}$ & Arokyry & $\begin{array}{l}\text { Watkë (possessivo associado a um nome) } \\
\text { Iwatkï (possessivo associado } \\
\text { a um pronome pessoal) }\end{array}$ \\
\hline $\begin{array}{l}\text { 36. pena, } \\
\text { pena do rabo, calda }\end{array}$ & $\begin{array}{l}\text { Ihpoty ['ihpoti] } \\
\text { Arokyry }\end{array}$ & $\begin{array}{l}\text { Pupot (possessivo associado a um nome) } \\
\text { ihpot (possessivo associado } \\
\text { a um pronome pessoal) } \\
\text { (kulasi) watkï }\end{array}$ \\
\hline 37. cabelo & Unsehpo & Umhet $\{i\}$ \\
\hline 38. cabeça & Upuhpo & $\begin{array}{l}\text { Uputpë (possessivo associado a um nome) } \\
\text {-uputpï (possessivo associado } \\
\text { a um pronome pessoal) }\end{array}$ \\
\hline
\end{tabular}




\begin{tabular}{|c|c|c|}
\hline $\begin{array}{l}\text { 39. Orelha } \\
\text { orelha de }\end{array}$ & $\begin{array}{l}\text { Pana } \\
\text { ipanary }\end{array}$ & $\begin{array}{l}\text { Pana } \\
\text { Ipana }\end{array}$ \\
\hline $\begin{array}{l}\text { 40. Olho } \\
\text { olho de }\end{array}$ & Onu & $\begin{array}{l}\text { Ëwu (Guiana), ëu (Brasil) } \\
- \text {-ewu, -eu }\end{array}$ \\
\hline $\begin{array}{l}\text { 41. nariz } \\
\text { nariz de }\end{array}$ & Ouna [ou'na] & $\begin{array}{l}\text { Ëmna } \\
\text {-emna }\end{array}$ \\
\hline $\begin{array}{l}\text { 42. boca } \\
\text { boca de }\end{array}$ & $\begin{array}{l}\text { Myhta } \\
\text {-mtary }\end{array}$ & $\begin{array}{l}\text { Mihta, } \\
\text {-mta }\end{array}$ \\
\hline 43. dente & $\begin{array}{l}\text { Zery } \\
\text {-zery }\end{array}$ & $\begin{array}{l}\text { Jelï } \\
\text {-je }\end{array}$ \\
\hline 44. língua & $\begin{array}{l}\text { Nuu } \\
\text {-nuuru }\end{array}$ & $\begin{array}{l}\text { NuU (Br.), enu (GFr.) } \\
-n \cup\{U\}\end{array}$ \\
\hline $\begin{array}{l}\text { 45. garra, unha } \\
\text { garra de, unha de }\end{array}$ & $\begin{array}{l}\text { Emasiu tutu } \\
\text { oma }\end{array}$ & $\begin{array}{l}\text { omo hawin } \\
\text { amo hawin }\end{array}$ \\
\hline 46. pé & Pupu & Pupu \\
\hline $\begin{array}{l}\text { 47. joelho } \\
\text { joelho de }\end{array}$ & $\begin{array}{l}\text { Osekumu } \\
\text {-esekumuru }\end{array}$ & $\begin{array}{l}\text { Ëhemu } \\
\text {-ehemu }\end{array}$ \\
\hline $\begin{array}{l}\text { 48. mão (genérico) } \\
\text { mão de }\end{array}$ & $\begin{array}{l}\text { Oma } \\
\text {-emary }\end{array}$ & $\begin{array}{l}\text { Omo } \\
\text {-amo }\end{array}$ \\
\hline 49. ventre, barriga & Mone & Mone \\
\hline $\begin{array}{l}\text { 50. pescoço (genérico) } \\
\text { Pescoço de }\end{array}$ & $\begin{array}{l}\text { Pymy } \\
\text {-pymyry }\end{array}$ & $\begin{array}{l}\text { Pimï } \\
\text {-pïmï }\end{array}$ \\
\hline Nuca & Pymy zehpyry & - \\
\hline $\begin{array}{l}\text { Garganta (genérico) } \\
\text { Garganta de }\end{array}$ & $\begin{array}{l}\text { Osena } \\
\text {-esenary }\end{array}$ & $\begin{array}{l}\text { Ëhena } \\
\text {-ehena }\end{array}$ \\
\hline 51. peito & Suhsu & Susu \\
\hline 52. coração & Oano & Wanë \\
\hline $\begin{array}{l}\text { 53. fígado } \\
\text { fígado de }\end{array}$ & $\begin{array}{l}\text { Ere } \\
\text {-erery }\end{array}$ & $\begin{array}{l}\text { Ële } \\
\text {-ele }\end{array}$ \\
\hline 54. beber & -oh (tohse) & -elï (tëlihe) \\
\hline 55. comer (comida ideal) & -ontuh (tontuhse) & -ëtuk (tëtukhe) \\
\hline 56. morder & -osekah (tosekahse) & -ë (tëhe) \\
\hline 57. olhar, ver & -ene (tonese) & -ene (tënei) \\
\hline 58. ouvir, entender & -ota (totase) & -panakma (tïpanakmai) \\
\hline 59. saber, conhecer & Uaro (tuaro) & Tuwalë \\
\hline 6o. dormir & -nyh (tynyhse & -ïnïk (tïnikse) \\
\hline 61. morrer & -orih (torihse) & $\begin{array}{l}\text {-lëmëp (tilëmëphe) 'recém morto' } \\
\text {-ëtalima (tëtalimai) } \\
\text { 'morto'(família próxima) } \\
\text {-lomo (tillomoi) 'enterrado' }\end{array}$ \\
\hline
\end{tabular}




\begin{tabular}{|c|c|c|}
\hline 62. matar & -uo (tuohse) & -uwë (tuwëi) \\
\hline 63. nadar & Toton-toton tykase & Toton-toton tïkai \\
\hline 64. voar & Poh-poh anko & Pom-pom tïkai \\
\hline 65. andar & Tyhty anko & Ïtë-tïtëi, tïhtï tïkai \\
\hline 66. vir & -oeh (toehse) & -umëk (tumëkhe) \\
\hline 67. deitar & $\begin{array}{l}\text { imihme (ase) [inmihme] } \\
\text { (de costas) } \\
\text { deitar alguém: } \\
\text {-axika (taxikase) } \\
\text { deitar-se: -ataxika } \\
\text { (tataxikase) }\end{array}$ & $\begin{array}{l}\text { (deitar no chão, lomona) tuntulam tïkai } \\
\text { (deitar na rede) etapna tuntulam tïkai }\end{array}$ \\
\hline $\begin{array}{l}\text { 68. sentar } \\
\text { Sentar-se no chão }\end{array}$ & $\begin{array}{l}\text { Kohroh kahsiko [koh'roh] } \\
\text { poroh- [toporohse] }\end{array}$ & Kolo tïkai 'tomar assento' \\
\hline 69. ficar em pé & Sikihme & Pilï \\
\hline 70. dar & Okarohse & -ekalë (tëkalëi) \\
\hline 71. dizer, contar & -ka (tykase) & -ka (tikai) \\
\hline 72. sol & Xixi & Sisi \\
\hline 73. lua & Nuno & Nunuwë \\
\hline 74. estrela & Xirikuato & Silikë \\
\hline 75. água & Tuna & Tuna \\
\hline 76. chuva & Konopo & Kopë \\
\hline 77. pedra & Topu & Tëpu \\
\hline $\begin{array}{l}\text { 78. areia, praia } \\
\text { (genérico) } \\
\text { (específico) }\end{array}$ & $\begin{array}{l}\text { sawa } \\
\text { isawany }\end{array}$ & $\begin{array}{l}\text { samut }\{1\} \\
\text { ihamut }\end{array}$ \\
\hline 79. terra & Nono ['nono] & Lo \\
\hline 8o. nuvem & Akurunu & Eklot \\
\hline 81. fumaça & Putom me [pu'tome] & Mutom \\
\hline 82. fogo & Apoto & Wapot \\
\hline 83. cinza & Oruno [oru:no] & Ëluwëtpë \\
\hline 84. queimar & -ahka (tyahkase) [tya'ka:se] & -ewa (tëwahe) \\
\hline $\begin{array}{l}\text { 85. caminho } \\
\text { Caminho de }\end{array}$ & $\begin{array}{l}\text { Osema } \\
\text {-esema }\end{array}$ & $\begin{array}{l}\text { Ëhema } \\
\text {-ehema }\end{array}$ \\
\hline 86. montanha, colina & Ypy & Ïpï \\
\hline 87. vermelho & Toapire & Takpile \\
\hline 88. verde & Kuri-Kuri ety & Kuli-Kuli wet \\
\hline 89. amarelo & Tawamano & Tawaman \\
\hline 90. branco & Karimutume & Tïkoloke \\
\hline
\end{tabular}




\begin{tabular}{|l|l|l|}
\hline 91. preto & Sinikutu mano ['mano] & Taliliman \\
\hline 92. noite & Koko & Koko \\
\hline $\begin{array}{l}\text { 93. quente (fogo) } \\
\text { calor (atmosférico) }\end{array}$ & $\begin{array}{l}\text { Asituno, } \\
\text { Piuka anko }\end{array}$ & $\begin{array}{l}\text { Asiphak, } \\
\text { Pikat tikai }\end{array}$ \\
\hline 94. frio & Konsikene [konsi'kene] & Këmï̈ken \\
\hline 95. cheio & Pehme & -uput (tuputse) \\
\hline 96. novo & Kasenato & Ihjan \\
\hline 97. bom & Kure & Ipok \\
\hline 98. circular, redondo & Merehme & Melem \\
\hline 99. seco & Tonore [to'nore] & Tïlasile \\
\hline 100. nome & Esety & -ehet \\
\hline
\end{tabular}

Esse quadro e muitos dos exemplos expostos acima evidenciam o parentesco lexical entre o aparai e o wayana. A lista de Swadesh mostra que essas duas línguas compartem uma parte de seu léxico, este grafado de uma mesma forma (tuna 'água', 'rio', koko 'noite', tawaman\{o\} 'amarelo') ou de forma ligeiramente diferente (ypy|ïï 'montanha') por deterem letras diferentes para um mesmo fonema. A lista mostra ainda vocábulos diferentes para um mesmo significado (nono|lo 'terra', azamo|ëjam 'piolho', kurelipok 'bem'). É ainda possível observar processos de redução vocálica (kana|ka, kaa 'peixe') e de permutação vocálica (oma-emary|omo-amo 'mão').

$* *$

Este estudo oferece uma variedade de dados que mostram uma parte de como o universo lexical do aparai e do wayana é constituído. Cada uma dessas línguas dispõe de uma infinidade de vocábulos próprios e compartimham um número importante deles; estes que às vezes apresentam uma mesma realização fonológica, outras pequenas diferenças. Novos vocábulos são constantemente incorporados no campo lexical; este não é fixo, ele não é imutável. Uma grande parte dos termos que designam objetos ocidentais integram o cotidiano desses grupos: ferramentas agrícolas, armas de fogo, redes de pesca, tecidos, roupas, calçados etc. Mesmo já tendo se ajustado morfofonologicamente ao sistema fonológico da língua, muitos dos termos revelam a sua origem e, em alguns casos, por qual meio o termo transitou: por afro-guianeses, por outros grupos indígenas, por eles mesmos. A criação de novas palavras parece ser uma prática recente entre os wayanas que vêem a necessidade de dispôr de termos técnicos não existentes nessas línguas, como 'dicionário', 'computador', 'carregador de bateria', entre outros. Uma vez palavras novas e palavras estrangeiras incorporadas no universo lexical de uma língua, seus usuários lhes dão vida, empregando-as indistintamente, sem nenhuma concorrência com o léxico que pertence à comunidade linguística. Esta as integra em seu campo lexical, que se enriquece quando as novas palavras passam a ser usadas nas mais distintas práticas sócio-culturais. 


\section{Referências}

ACT. Wayana baseline study. Final Report. 2007. Disponível em < http://www.act-suriname.org/wpcontent/uploads/2015/05/Wayana-Baseline-Study 2007.pdf>.

ALBY, Sophie; Isabelle LEGLISE. Plurilinguisme et éducation en Guyane. Les langues de Guyane. In Langues et cité. Bulletin de l'observatoire des pratiques linguistiques, 2017, p. 10-11.

BRIGHTMAN Marc, Vanessa GROTTI. First Contacts, Slavery and Kinship in orth Eastern Amazonia. In BRIGTHMAN, M.; FAUSTO, C.; GROTTI, V. (Eds.). Ownership and Nature: Studies in Native Amazonian Property Relations. New York: Berghahn Books, 2016. Disponível em: <https://www.ncbi.nlm.nih.gov/ books/NBK436748/>

CÁCCAMO, Celso Alvarez. "Osmose" e redes sociais na transmissão da língua: O papel dos locais sociais, 2004. Disponível em <http://www.udc.es/dep/lx/cac/escritos/20040229-osmose.htm>

CAMARGO, Eliane. Identidade étnica, identidade lingüística: o bilingüismo entre os Wayana e os Aparai. In Multilingüismo em Foco. Estudos da Linguagem: limites e espaços. Rio de Janeiro, UFRJ. 1997. Mesa-Redonda do VI Congresso da ASSEL-Rio. p. 89-99.

CAMARGO, Eliane. Aspects de la morphologie nominale aparai: I'appartenance. In Langues de Guyane. Amerindia, Paris, AEA, v. 26, p. 109-132, 2001.

CAMARGO, Eliane. Lexical categories and word formation processes in Wayana (Cariban language), LOIS, X.; VAPNARSKY, V. (Eds). Lexical categories and Root Classes in Amerindian Languages, Peter Lang, 2006. p.147-188.

CAMARGO, Eliane. Les Wayana. In Langues de Guyane. GOURY; LESCURE (Eds.). Coleção Culture en Guyane. Vents d'Ailleurs-IRD éditions. p. 78-89, 2009.

CAMARGO, Eliane; GRENAND, Pierre. Un peuple Karib: les Wayana, In GRENAND (Dir.). Encyclopédies palikur, wayana et wayampi. Fascicule: «Langue, milieu et histoire», CTHS, Paris, p. 60-87, 2009.

CAMARGO, Eliane; Amparo IBANEZ. Chercheurs de mots em terres apalaï et wayana. Ed. Migrilude. 2015 .

CAMARGO, Eliane; WAJANA, Asiwae; TORIBIO, Alberto Roque. Documentação de línguas e culturas indígenas. Revista Moara. Edição 50, Estudos Linguísticos. p. 52-86. 2018, ago-dez. Disponível em https://periodicos.ufpa.br/index.php/moara/article/view/6805/5372

CAMARGO, Eliane; WAJANA, Asiwae. Estratégias da posse em wayana e seu mosaico morfo(fono) lógico. Perspectiva tipológica. LIAMES. Campinas, v. 19, p. 1-33, 2019.

CAMARGO, Eliane; WAJANA, Asiwae. Mope et Pitou à la pêche. Paris: Ipê éditions, 2019.

CAMARGO, Eliane; TAPINKILI, Anaiman. Le wayana au coeur des mots. Dictionnaire analogique bilíngue wayana-français. Éditions CTHS-Éditions Ipê, 2020.

CAMARGO, Éliane; TANDAR, Sara; HOLGUIN, Veronica et alli. L'Amazonie amérindienne dans l'ère du numérique: le portail multilingue WATAU. Patrimoines du Sud, 2020. Disponível em: <https://journals. openedition.org/pds/5127>. 
FREIRE, José Ribamar Bessa. Da língua geral ao português: Para uma história dos usos sociais das línguas na Amazônia. 2003. Tese (Doutorado), Universidade do Estado do Rio de Janeiro, Rio de Janeiro, 2003. GALLOIS, Dominique Tilkin. Migração, guerra e comércio: Os waiapi na Guiana. Antropologia. São Paulo: FFLCH- USP, 1986.

GOURY, Laurence et al. Des médiateurs bilingues en Guyane française. Revue française de linguistique appliquée. v. V, 2000/2, p. 43-6o.

GRENAND Françoise. Dictionnaire wayãpi-français. Lexique français-wayãpi. Paris: Peeters/Selaf, 1989. GRENAND Pierre et alli. Parmacopées traditionnelles en Guyane. Créoles, Wayãpi, Palikur. Paris, IRD, 2004.

GRENAND, Pierre. Ainsi parlaient nos ancêtres. Essai d'ethnohistoire «wayãpi». Travaux et documents de l'O.R.S.T.O.M. n.148. Editions de l'office de la Recherche scientifique et technique outre-mer. Paris: ORSTOM, 1982.

GRENAND Pierre; Françoise GRENAND. La question amérindienne en Guyane française: Les Wayana. Ethnies (FRA), v. 1, n. 1-2, p. 23-24, 1985.

HURAULT, Jean. Les Indiens de Guyane française: problèmes pratiques d'administration et de contacts de civilisation. New West Indian Guide. Published by Bill, p. 81-186, 1962-1963. Disponível em: <https:// www.jstor.org/stable/41849385>.

JOLKESKY, Marcelo Pinho De Valhery. Estudo arqueo-ecolinguístico das terras tropicais sul-americanas. 2016. Tese (Doutorado em Linguística), Universidade de Brasília, Brsília, 2016.

KOEHN, Sally Sharp. The use of generic terms in Apalaí genitive construction. Revista Latinoamericana de Estudios Etnolingüísticos. Lima: Ponencia al Simposio "Tupi-Guarani/Carib linguistics", 470 CIA, New Orleans, 1991, p. 39-48.

KOEHN, Edward H.; Sally Sharp KOEHN. Vocabulário básico Apalaí-Português: Dicionário da língua Apalaí, Brasilia, Sociedade Internacional de Lingüística, 1995. 163 p.

KOEHN, Edward H.; Sally Sharp KOEHN. Fonologia da língua apalaí. In GUDSCHINSKY, S.C. (Ed.). Estudos sôbre línguas e culturas indígenas, t. II, Brasília: Instituto Lingüístico de Verão, 1971, p. 17-28.

LEITE, Serafim. História da Companhia de Jesus no Brasil. Tomo III. Fundações e entradas, séculos XVIIXVIII. Rio de Janeiro: Instituto Nacional do Livro; Lisboa: Livraria Portugália, 1943.

MEIRA, Sérgio. A família linguística Caribe (Karíb). Revista de Estudos e Pesquisas. FUNAl, Brasília, v. 3, n.1/2, p. 157-174, jul./dez. 2006.

MORGADO, Paula. Pluralismo médico Wayanã-Aparaí: uma experiência intercultural. 1994. Dissertação (Mestrado), Faculdade de Filosofia, Letras e Ciêncuas Humans, Universidade de São Paulo, São Paulo, 1994. 318. Disponível em <http://morgadodl1.tempsite.ws/paula/mestrado/index.htm.>

RICE, Frederick Joh Duval. Short Aparai vocabulary. In: Journal de la Société des Américanistes, t. $23, \mathrm{n}$. 1, 1931, p. 115-120. Disponível em <https://doi.org/10.3406/jsa.1931.1086>.

SOUTY, François J. L. Aux orgines de I'histoire guyanaise (XVle-XVIle siècles): El Dorado etla Gyane, mythe et réalité. Outre-Mers Revue d'histoire 272, p. 303-334, 1986. 
SWADESH, Morris. Lexico-statistic dating of prehistoric ethnic contacts. With special reference to North American Indians and Eskimos. Proceedings of theAmerican Philosophical Society. 96. p. 452-463, 1952. Disponível em: <https://fr.wikipedia.org/wiki/Liste_Swadesh>

VAN VELTHEM, Lucia H. A pele de Tuluperê. Uma etnografia dos trançados Wayana. PR/McT/Cnpq. 1998.

\section{Abreviaturas}

Ap aparai

Wa wayana

Lit literal 